\title{
AVALIAÇÃO DO POTENCIAL CARCINOGÊNICO DOS AGENTES CLAREADORES DENTAIS
}

\author{
DAYSE APARECIDA PIEROLI
}

Dissertação apresentada à Faculdade de Odontologia de Bauru, Universidade de São Paulo, como parte dos requisitos para a obtenção do grau de Mestre em Odontologia

- Área de Dentística

Orientadora:

Profa. Dra. Maria Fidela de Lima Navarro

BAURU

1997 


\section{DAYSE APARECIDA PIEROLI}

Nascimento

1987 - 1990 -

1992/1994 -

1994 -

1995 - 1997 -

Associações -
17 de julho de 1966- Pirajuí, São Paulo

Curso de Odontologia

Universidade de Uberaba- UNIUBE - Minas Gerais

Bolsista de Aperfeiçoamento/Especialização

Departamento de Dentística da FOB - USP

Curso de Especialização em Endodontia

na Faculdade de Odontologia de Bauru - USP

Curso de Pós-Graduação em Dentística em nível de Mestrado na Faculdade de Odontologia de Bauru, USP.

Sociedade Brasileira de Pesquisas Odontológicas (SBPqO) - Divisão Brasileira da IADR

International Association for Dental Research - IADR 


\section{DEDICATÓRIA}


Dedico este trabalho,

À Deus, acima de tudo, pois sem a sua permissão e bondade nada seria possível.

Aos meus pais, pela compreensão e apoio em todos os momentos da minha vida e pela maneira que me educaram, ensinando a não desistir diante das dificuldades e acreditar na minha capacidade de superá-las.

Ao meu marido, Ênio, pelo companheirismo, carinho, apoio sempre presentes e pela compreensão e respeito pela minha vida profissional; pela forma com que soube enfrentar, com sua paciência mineira, os momentos difíceis que passamos e com os quais aprendemos muito; pela dedicação carinhosa ao nosso filho nos momentos em que estive ausente.

Ao meu filho Gabriel, por ser essa luz divina iluminando nossa vida com amor e alegria e nos dando alento nas horas mais difíceis. Agradeço todos os dias pela felicidade de tê-lo como filho.

À minha irmã Inês, pela sua força interior e perseverança em alcançar os seus objetivos, sendo um exemplo de coragem para mim. Ao meu cunhado Roberto e minhas sobrinhas Kelly e Érica pela participação, presença e carinho constantes em todas as etapas da minha vida. 


\section{AGRADECIMENTOS}


Agradeço de maneira especial à Professora Doutora MARIA FIDELA DE LIMA NAVARRO, pela maneira com que sempre me apoiou e incentivou neste trabalho e por contagiar a todos que estão a sua volta com a sua disposição para trabalhar, sendo um exemplo dinamismo e coragem. 


\section{AGRADECIMENTOS}

À Faculdade de Odontologia de Bauru, Universidade de São Paulo, na pessoa do Diretor Prof. Dr. Dagoberto Sotovia Filho.

À Coordenadoria do Curso de pós-graduação, na pessoa do Senhor Professor Doutor Luís Fernando Pegoraro.

Aos Professores Doutores do Departamento de Dentística: José Mondelli, Carlos Eduardo Francischone, José Carlos Pereira, Mário Honorato da Silva e Souza Jr., João Lúcio Coradazzi, Eduardo Batista Franco, Áquira Ishikiriama, pelos conhecimentos transmitidos.

Aos professores do Departamento de Patologia da Faculdade de Odontologia de Bauru USP, pela atenção a mim dispensada e principalmente ao Prof. Dr. Alberto Consolaro pela co-orientação deste trabalho.

Aos funcionários do Departamento de Dentística da Faculdade de Odontologia de BauruUSP, especialmente a Eloísa, Ângela e Nelson pela amizade, atenção e carinho com que sempre me atenderam.

Aos funcionários do Departamento de Patologia da Faculdade de Odontologia de Bauru USP, Valdir, D.Cida e Jurão que acompanharam o desenvolvimento deste trabalho e pela maneira atenciosa com que sempre me trataram.

À minha querida amiga Maria Cristina Felipe Carrara, ex-funcionária do Departamento de Patologia da FOB - USP, pela indispensável participação e auxílio na fase experimental deste trabalho.

Ao Departamento de Patologia da Faculdade de Odontologia da Universidade de São Paulo, na pessoa da $\operatorname{Prof}^{\mathrm{a}} \operatorname{Dr}^{\mathrm{a}}$ Vera Cavalcanti de Araújo pelo auxílio e atenção a mim dispensados.

À Prof ${ }^{\mathrm{a}} \operatorname{Dr}^{\mathrm{a}}$ Denise Tostes de Oliveira do Departamento de Patologia FOB - USP, pela amizade, atenção e colaboração na montagem fotográfica deste trabalho. 
Aos meus amigos e companheiros de Pós-graduação, Alessandro Costa Pereira, Evelyn Almeida Lucas Gonçalves, Mário James dos Anjos Silva, pela atenção, carinho e amizade com que me auxiliaram na compreensão sobre Patologia.

Ao Prof. Dr. Carlos Fernandes Salles e a Prof ${ }^{a}$ Renata Correa Pascoto pela atenção e amizade.

Aos meus sogros, Lídia e Alceu, cunhados, Adriana, Eduardo e Fábio, pelo carinho, apoio e incentivo.

Aos funcionários da Biblioteca da FOB - USP pela atenção, presteza e amizade.

Aos funcionários da Reprografia, que durante toda a fase experimental deste trabalho separaram e guardaram os papéis picados utilizados diariamente nas gaiolas dos animais.

Aos funcionários do Curso de pós-graduação, Neide, Sandra, Aninha e Heloísa pela amizade, carinho e atenção sempre presentes.

Aos meus colegas do Curso de pós-graduação, pela amizade e pelo convívio.

À Fundação de Amparo e Pesquisa do Estado de São Paulo - FAPESP, pêlos recursos financeiros proporcionados.

A todos que direta ou indiretamente contribuíram para o desenvolvimento deste trabalho. 


\section{SUMÁRIO}

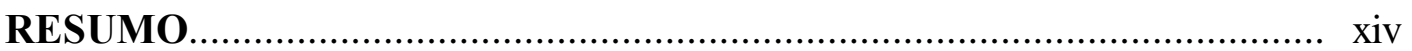

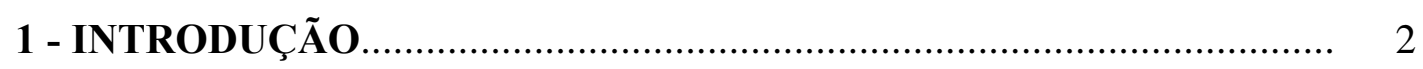

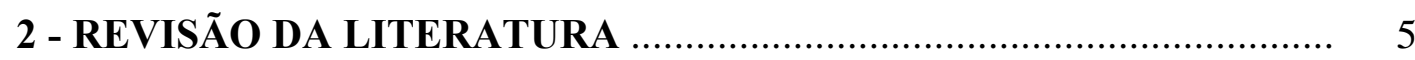

2.1 - Carcinogênese química bucal..................................................................................... 6

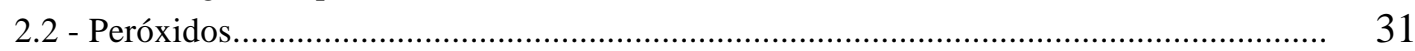

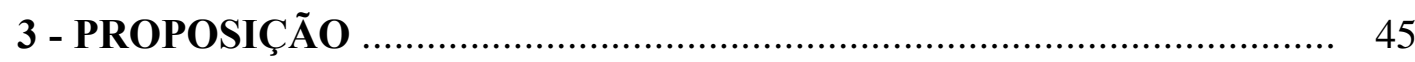

4 - MATERIAL E MÉTODOS............................................................... 47

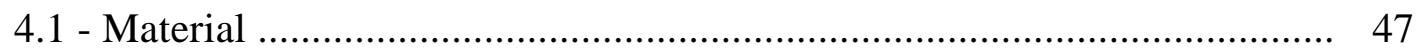

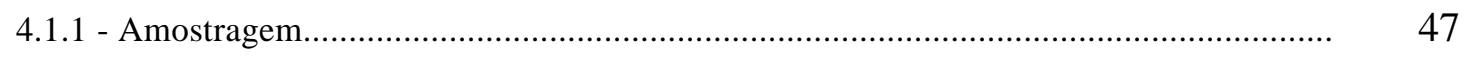

4.1.2 - Distribuição.............................................................................................................. 48

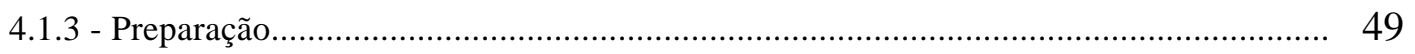

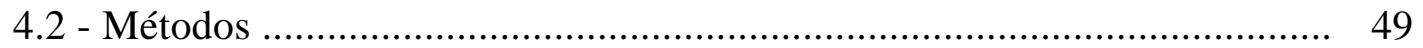

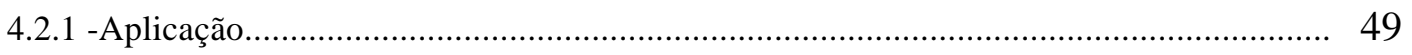

4.2.2 -Sacrifício dos animais, obtenção e preparação dos espécimes........................................ 50

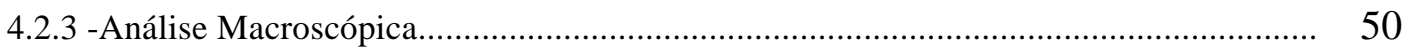

4.2.4 -Análise Microscópica....................................................................................... 51

4.2.4.1 -Mucosa Normal.......................................................................................... 51

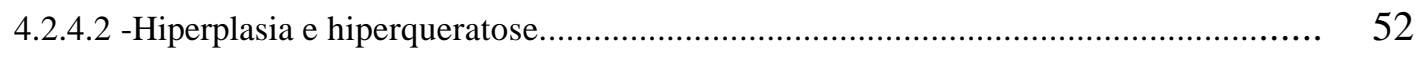

4.2.4.2.1 Sem displasia epitelial......................................................................... 52

4.2.4.2.2 Com displasia epitelial........................................................................ 53

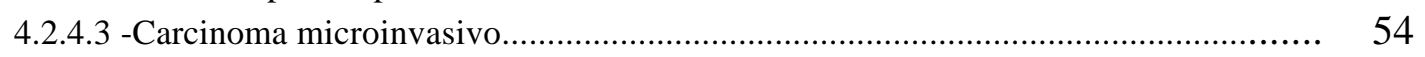

4.2.4.4 -Carcinoma invasivo sem metástase aparente.......................................................... 54

4.2.4.5 -Carcinoma invasivo com metástase aparente............................................................. 54

5 - RESULTADOS

5.1 -Análise Macroscópica......................................................................................................

57

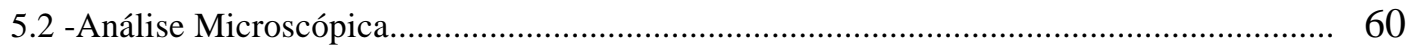

6 - DISCUSSÃO

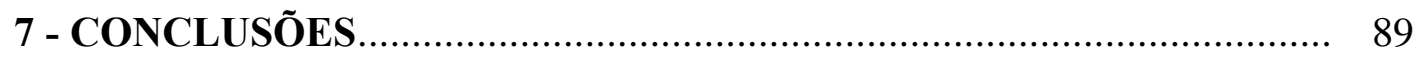

REFERÊNCIAS BIBLIOGRÁFICAS................................................. 92

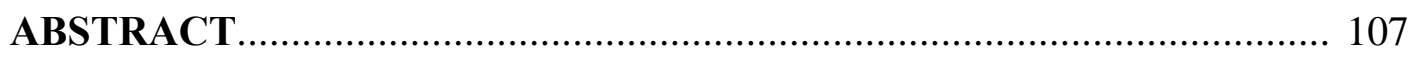




\section{RESUMO}




\section{RESUMO}

A característica primordial da carcinogênese é o somatório de efeitos nas células. Na etiopatogenia do câncer bucal vários fatores estão envolvidos principalmente o álcool, o fumo e as radiações solares. Além disso, muitas outras substâncias potencialmente carcinogênicas estão em contato diário com a mucosa bucal e encontram-se presentes nos medicamentos, nos alimentos e no próprio meio ambiente como os gases industriais. Devido ao efeito somatório sobre as células, toda e qualquer substância deve ser avaliada quanto ao seu potencial carcinogênico sobre a mucosa bucal. Neste aspecto, a boca constitui o local mais submetido à ação carcinogênica do organismo humano. Com a introdução do peróxido de carbamida a 10\% na clareação de dentes vitalizados, surgiram controvérsias significativas quanto ao risco de se danificar os tecidos moles, seja pelo contato direto ou pela ingestão do produto durante o processo clareador. Na técnica caseira de clareação, a partir da utilização de uma moldeira de acetato confeccionada pelo profissional, o paciente faz a aplicação da substância não havendo um controle direto sobre a quantidade utilizada ou ingerida e o tempo de exposição ao agente clareador. Desta forma, existe uma preocupação quanto ao potencial carcinogênico destas substâncias. A partir do modelo experimental de DMBA-indução para carcinogênese química, propusemos estudar os efeitos de dois agentes clareadores à base de peróxido de carbamida a 10\%, com e sem carbopol, utilizando hamsters sírios dourados. Os animais foram divididos em 7 grupos experimentais com 10 animais cada e as substâncias foram pinceladas, durante 20 semanas, na porção média da borda lateral lingual dos animais. Os grupos foram assim divididos: 
Grupo I (Acetona); Grupo II e III (peróxido de carbamida a 10\% com e sem carbopol, respectivamente); Grupo IV (dimethilbenzantraceno - DMBA); Grupo V (DMBA + peróxido de carbamida a 10\% com carbopol); Grupo VI (DMBA + peróxido de carbamida a 10\% sem carbopol) e Grupo VII (água destilada). Nos grupos com a aplicação da acetona, do peróxido de carbamida com e sem carbopol e da água destilada, a mucosa lingual não revelou alterações displásicas e/ou neoplásicas. No Grupo IV, observou-se displasia em 4 dos animais e carcinomas epidermóides nos 6 restantes, sendo 3 microinvasivos e 3 invasivos. No Grupo V, todos os 9 animais desenvolveram carcinomas epidermóides, sendo 2 microinvasivos e 7 invasivos. No Grupo VI, de 9 animais observados, 1 apresentou hiperplasia intensa e 8 carcinomas epidermóides invasivos. Concluiu-se que os clareadores à base de peróxido de carbamida a 10\%, com ou sem carbopol, potencializaram o efeito do carcinógeno, no caso o DMBA (ácido dimethilbenzantraceno), atuando provavelmente na fase de promoção tumoral. Desta forma, considerando o caráter somatório das alterações carcinogênicas nas células, este efeito potencializador também pode acontecer com os demais agentes carcinógenos que atuam sobre a mucosa bucal. Os resultados sugerem que a clareação dentária deva ser executada pelo profissional, em seu consultório, com total proteção da mucosa bucal pelo isolamento absoluto, evitando-se a exposição do paciente aos riscos desnecessários, preservando a sua saúde. 


\section{1 - INTRODUÇÃO}




\section{1- INTRODUÇÃO}

A característica primordial da carcinogênese é o somatório de efeitos nas células. Na etiopatogenia do câncer bucal vários fatores estão envolvidos principalmente o álcool, o fumo e as radiações solares. Muitas outras substâncias, potencialmente carcinogênicas, estão em contato diário com a mucosa bucal e existem nos medicamentos, nos alimentos e no próprio meio ambiente como os gases industriais ${ }^{64,65,82,83}$.

Os agentes clareadores à base de peróxido de carbamida a $10 \%$ são utilizados com freqüência na técnica de clareação caseira de dentes vitalizados. Estas substâncias podem ser encontradas em 2 classes: com e sem carbopol, um polímero de carboxipolimetileno. A presença do carbopol aumenta a viscosidade do produto, melhora a sua aderência ao dente e retarda a liberação do oxigênio ${ }^{1,5,22,23}$. Na técnica caseira de clareação, o próprio paciente faz a aplicação do agente clareador em casa, utilizando uma moldeira de acetato confeccionada no consultório. O paciente é orientado quanto à forma correta de utilizar o produto e o tratamento é supervisionado pelo profissional. Existe uma preocupação em relação ao uso dessas substâncias sem nenhuma proteção dos tecidos moles, e também quanto à sua ingestão durante o tratamento, expondo o paciente ao contato direto com a substância. A preocupação maior é quanto ao potencial carcinogênico dessas soluções.

Devido ao efeito somatório sobre as células, todo e qualquer agente potencialmente carcinogênico deve ser avaliado quanto à sua ação sobre a mucosa bucal, pois somar-se-á aos efeitos dos demais. A boca, neste aspecto, constitui-se no local mais submetido a ação carcinogênica do organismo humano, juntamente com a pele. 
Há trabalhos como de WeITZMAnN ${ }^{93}$, HiROTA; YoKOYAMA ${ }^{43}$, ITO et al. ${ }^{49}$ que analisaram o potencial carcinogênico do peróxido de hidrogênio, um componente ativo do peróxido de carbamida a $10 \%$, e constataram o seu efeito carcinogênico no desenvolvimento de carcinomas em modelos experimentais em roedores.

O modelo experimental de DMBA-indução para carcinogênese química bucal, em hamsters sírios dourados, foi inicialmente preconizados por SALLEY ${ }^{80,81}$, FUJITA et al. $^{31,32}$, EVESON; MACDONALD ${ }^{25}$, MAREFAT $^{60}$, MAREFAT; $_{\text {ShKLAR }}{ }^{61}$ e MORRIS $^{67 .}$ Recentemente, foi descrito por FASSONI et al. ${ }^{27}$.

O objetivo deste trabalho é avaliar comparativamente o potencial carcinogênico de dois agentes clareadores dentais no modelo DMBA-indução para carcinogênese química bucal. 


\section{2 - REVISÃO DE LITERATURA}




\section{2 - REVISÃO DE LITERATURA}

A carcinogênese química bucal induzida é utilizada há muito tempo na investigação de diversas substâncias químicas quanto aos seus possíveis efeitos carcinogênicos ou co-carcinogênicos. Inúmeros trabalhos relatam os efeitos carcinogênicos de substâncias existentes em nosso meio ambiente, onde estamos em contato diário, tais como: o álcool, o fumo, os aditivos alimentares, os gases industriais e também as radiações solares.

Atualmente, a crescente utilização de substâncias para clarear os dentes, muitas vezes de forma indiscriminada, torna-se uma preocupação. Levando-se em consideração a etiologia multifatorial do câncer e os escassos trabalhos na literatura testando o possível efeito carcinogênico dos clareadores nos instigaram a estudá-los mais profundamente.

Inicialmente, nesse capítulo, abordaremos alguns aspectos relacionados ao desenvolvimento da carcinogênese bucal quimicamente induzida e o desenvolvimento de neoplasias provocado pelo contato de substâncias carcinógenas existentes no meio ambiente e das quais fazemos uso direta ou indiretamente. Posteriormente, enfocaremos trabalhos relacionados ao peróxido de carbamida quanto à sua composição, efeitos nos tecidos, citotoxidade e a relação dos peróxidos com fatores mutagênicos. 


\section{1 - Carcinogênese química bucal}

A carcinogênese é um processo dinâmico caracterizado por múltiplas etapas definidas como: iniciação, promoção, progressão e manifestaçãoo ${ }^{32,36,42,69,70,78}$. A iniciação corresponde ao primeiro passo para o desenvolvimento neoplásico, sendo irreversível, porque lesa de forma permanente a estrutura do DNA. Uma vez a célula iniciada, passa por um período de latência, que corresponde ao intervalo entre a exposição ao carcinógeno e o aparecimento de lesões neoplásicas visíveis. As células iniciadas, em contato com agentes promotores passam a expressar suas alterações antes latentes. É o estágio de promoção da carcinogênese onde os promotores estimulam a proliferação celular e modulam sua diferenciação com o aparecimento de uma nova população celular com propriedades diferentes da célula inicial, gerando a neoplasia. Os agentes promotores chamados de co-carcinógenos, aumentam a atividade oncogenética dos carcinógenos e aceleram a transformação neoplásica das células. As etapas seguintes são: a progressão onde ocorre a evolução da neoplasia maligna até a etapa da manifestação clínica do câncer. $O$ agente iniciador então, propicia uma alteração permanente nas células e sua evolução para uma neoplasia pode ser de forma lenta ou rápida, só depende da interação com um agente promotor ${ }^{36,76,77,78}$. Os agentes promotores apresentam um papel importante, no desenvolvimento de câncer em seres humanos, pelo fato de serem abundantes no meio ambiente. Podem ser tanto por fatores exógenos, tais como: químicos, físicos e biológicos, que estão relacionados ao estilo de vida e hábitos 
alimentares do indivíduo como por fatores endógenos, como: fatores genéticos, hormonais e imunológicos $37,38,42,64,65,88$.

O efeito co-carcinogênico da resina de cróton foi avaliado por BEREMBLUM ${ }^{8}$, em 1941, objetivando determinar a natureza da ação carcinogênica e sua relação com o processo de carcinogênese. A resina de cróton sendo aplicada antes do benzopireno, por um período de 26 semanas, falhou na sua influência à resposta na pele de ratos; no entanto, quando foi aplicada após o benzopireno, aumentou o desenvolvimento de tumores. Em relação aos resultados, observou-se que a resina aplicada antes do carcinógeno não influenciou no desenvolvimento tumoral, mas após o tratamento, ela elevou os índices tumorais. A resina de cróton pode ser considerada um co-carcinógeno, mas não pode produzir tumores per si.

A carcinogênese química bucal teve início com as investigações de SALLEY ${ }^{80}$, em 1954, demonstrando que os carcinomas espinocelulares poderiam ser produzidos em mucosa bucal de bolsa de bochecha de hâmsters, por meio de múltiplas aplicações locais de agentes carcinogênicos químicos, como o DMBA. Os objetivos foram avaliar a suscetibilidade do epitélio da bolsa da bochecha de hâmster à ação de agentes carcinogênicos químicos como o DMBA, metilcolantreno e benzopireno, e determinar o carcinógeno a ser utilizado em futuras investigações. Neste trabalho, o autor observou que a solução de DMBA diluída em acetona promoveu os melhores resultados sendo que os demais apresentaram resultados positivos, porém em proporção menor. Os tumores 
desenvolvidos variaram de papilomas a carcinomas espinocelulares com metástases para linfonodos regionais.

SALLEY ${ }^{81}$, em 1957, avaliou as alterações microscópicas na bolsa da bochecha de hâmster, em estágios sucessivos durante o processo de indução tumoral por DMBA e comparou estes achados com os descritos previamente para a pele. Constatou que havia pelo menos quatro estágios precedentes à neoplasia induzida, sendo eles: inflamação, degeneração, regeneração e hiperplasia e que estes resultados encontrados foram similares aos descritos para a pele tratada com carcinógenos químicos.

MORRIS $^{67}$, em 1961, avaliou alguns fatores que poderiam influenciar no desenvolvimento de neoplasias experimentais. Foram separados três fatores para serem analisados: idade do animal, freqüência de aplicação da droga e concentração do carcinógeno. Quanto ao fator idade do animal, no início do experimento, constatou-se a ausência de diferença, no período de latência para o desenvolvimento de tumores quando se compararam animais com 3, 6 e 9 meses de idade e notou-se um período latente maior em animais com 18 meses de idade. No início do experimento, os animais selecionados deveriam ter uma idade média ideal de 5 meses. Neste caso, foi questionado se a influência do desenvolvimento tumoral está em relação à concentração da droga com o peso corporal, ou mesmo, se os animais mais jovens, com maior metabolismo tecidual, tinham maior suscetibilidade à ação da droga. Quanto ao fator freqüência de aplicações da droga, concluiu-se pelas 3 aplicações semanais, pois o período de latência para o desenvolvimento tumoral foi mais curto quando comparado às 2 aplicações semanais. Em 
relação à concentração do carcinógeno, foram feitas diluições do DMBA em óleo mineral, testando as concentrações de $1,5 \%, 0,5 \%, 0,1 \%$ e $0,05 \%$. Nas duas últimas diluições as reações foram muito leves ou até inexistentes. Com a concentração de 1,5\% a reação foi muito intensa, após a segunda aplicação, provocando a morte de vários animais. Nos animais sobreviventes, o tempo requerido para o desenvolvimento tumoral foi praticamente o mesmo para os animais que receberam a droga em concentração de 0,5\%. No grupo de $0,5 \%$, no entanto, as condições físicas foram extremamente melhores, estabelecendo-se a concentração de $0,5 \%$ como a ideal. As diferenças quanto ao sexo dos animais não interferiram nos resultados, assim como as condições de cativeiro.

KELLER; TERRIS ${ }^{52}$, em 1965, avaliaram vários casos de cânceres bucal e faringeano e encontraram uma grande associação com cirrose hepática e com alto consumo de álcool e fumo independentemente. Neste trabalho, foram avaliados 598 pacientes, os dados incluíram a idade, a ocupação, o consumo de álcool, o uso de tabaco, o diagnóstico de cirrose hepática e as preferências religiosas na incidência desses tipos de cânceres. Observaram que os judeus apresentavam uma baixa incidência desses cânceres. Ao avaliar os hábitos desses grupos religiosos, constataram um baixo consumo de álcool, porém um grande uso de tabaco, em comparação com outros grupos. A incidência de câncer entre os judeus foi menor que nos demais grupos. Os autores concluíram que existe uma correlação entre o consumo de álcool, tabaco e o câncer bucal e faringeano.

$\mathrm{SHAW}^{84}$, em 1970, descreveu que muitos agentes químicos, físicos e biológicos podem causar mudanças (quebras) nos cromossomos humanos e mutação genética. Essas 
mudanças nos genes e cromossomos não produzem perigo imediato à saúde porém, as alterações podem ser indetectáveis por vários anos ou gerações. O autor relacionou vários componentes químicos e físicos que existem em nosso meio e que podem causar mudanças nas células. Como exemplo temos os aditivos alimentares e conservantes (nitrato de sódio presente nos defumados, ciclamato (adoçante), glutamato monossódio (espessante), benzopireno - hidrocarbonetos aromáticos (combustão do tabaco), aflatoxina B1 (toxina produzida pelo fungo “Aspergilus flavus” devido à má conservação de grãos, como por exemplo, o amendoim) e muitos outros componentes.

FUJITA et al. ${ }^{31}$, em 1973, realizaram um dos primeiros trabalhos, em língua de hamster, conseguindo uma metodologia mais eficiente para produzir uma maior incidência de carcinoma lingual em um tempo menor. Os animais foram divididos em 5 grupos com um total de 82 animais. O grupo 1 recebeu aplicações de DMBA a 0,5\%, em acetona, três vezes por semana, no terço médio da borda lateral da língua, precedidas por escarificação; o grupo 2 teve o mesmo procedimento sem escarificação prévia; o grupo 3 recebeu aplicações de acetona, com escarificação prévia; o grupo 4 recebeu apenas acetona; o grupo 5 só escarificação; e o grupo 6 não foi tratado. Os animais foram observados até a sua morte. Como resultado o autor observou no grupo 1 ulcerações com 24 horas e todos os animais morreram em 27 semanas. O grupo 2 não apresentou ulceração e, com 20 semanas, 1 animal apresentou tumor. Ao final de 27 semanas, 4 animais morreram e os demais continuaram a desenvolver tumor. Os grupos restantes não desenvolveram tumor. A diferença entre os grupos 1 e 2 foi significativa, e neste caso, o 
fator escarificação funcionou como porta de entrada do carcinógeno e o epitélio da área escarificada, por estar em regeneração tornou-se susceptível à ação do carcinógeno.

Ainda em 1973, FUJITA et al. ${ }^{32}$, com o objetivo de estabelecer uma metodologia experimental de carcinogênese química, semelhante ao que ocorre no homem, avaliaram qual o local da língua mais susceptível à indução química tumoral e o seu grau de malignidade. Avaliaram cinco regiões linguais com aplicação de DMBA utilizando hamsters e dividindo-os em cinco grupos. O grupo 1 recebeu aplicações na porção média da borda lateral da língua; o grupo 2 na porção anterior da borda lateral da língua; o grupo 3 na porção média do dorso lingual; o grupo 4, ponta da língua; e o grupo 5, porção ventral da língua. As aplicações foram feitas com DMBA a 0,5\% em acetona, 3 vezes por semana, após escarificação local. Como mostram os resultados o período de latência foi significativamente menor para o grupo 1 e as metástases regionais e a infiltração tecidual foram mais frequientes neste grupo. Os grupos 2, 3, 4 e 5 foram intermediários, seguindose o grupo 3, que necessitou de período experimental muito maior para o desenvolvimento tumoral.

MILLER ${ }^{64}$, em 1978, no 68th Anual Meeting of the American Association for Cancer Research, Denver, Colorado, abordou alguns aspectos relacionados à carcinogênese química em humanos. A apresentação se referiu às causas dos cânceres humanos, relacionando-os ao meio ambiente, radiação solar e produtos químicos que funcionam como carcinógenos naturais ou sintéticos. Epidemiologistas afirmam que 60\% a 90\% dos cânceres humanos têm fatores do meio ambiente na sua etiologia. A radiação 
solar constitui um importante fator causal de câncer de pele, e uma maior ênfase tem sido dada às substâncias químicas consideradas como principal fator etiológico de câncer em humanos. Miller discorreu ainda sobre o desenvolvimento da carcinogênese desde o seu início onde os primeiros estudos foram feitos através da observação de pessoas que trabalhavam com produtos químicos e que desenvolveram câncer. A partir de 1940, os carcinógenos químicos passaram a ser conhecidos e estudados. A carcinogênese é um processo de múltiplas etapas começando pela iniciação tumoral que pode ser efetuada por uma simples dose de um carcinógeno, como um agente alquilante, hidrocarbono aromático. A fase de iniciação tem como característica se completar rapidamente e ser irreversível; a segunda etapa é a promoção que ocorre em um período de semanas ou meses e requer repetidas doses de um promotor.

ELZAY ${ }^{24}$, em 1978, avaliou o álcool e o fumo como agentes promotores no modelo de carcinogênese em hamsters. Foram utilizados 174 animais separados em 6 grupos de 29 animais. O carcinógeno utilizado foi o DMBA a 0,5\% em óleo de cróton e os animais receberam as substâncias por 21 semanas. O grupo I recebeu DMBA + álcool + fumo, o grupo II recebeu DMBA + álcool, o grupo III recebeu DMBA + fumo, grupo IV recebeu DMBA, grupo V álcool + fumo e grupo VI fumo. Eles constataram que o consumo do álcool e do fumo quando sózinhos ou associados, aumentaram a incidência de câncer bucal.

FREEDMAN; SHKLAR ${ }^{28}$, também em 1978, avaliaram o potencial carcinogênico do álcool no modelo de carcinogênese em hamsters. Foram utilizados 40 animais divididos em 4 grupos recebendo três aplicações por semana durante 14 semanas 
. Os grupos se dividiram da seguinte maneira: grupo I DMBA; grupo II DMBA + álcool; grupo III controle; grupo IV álcool. O álcool foi colocado na água de beber. Como resultado, observaram que no grupo do álcool (IV) não houve o aparecimento de carcinoma, porém no grupo em que ocorreu a associação do álcool com o DMBA, após 14 semanas, foram observados displasias e carcinomas epidermóides, permitindo concluir que o álcool, por si só, não é carcinogênico, porém apresentam um efeito cocarcinogênico, agindo na promoção de carcinogênese.

FRIDOVICH ${ }^{30}$, em 1978, fez uma análise sobre os radicais superóxidos presentes no organismo salientando a toxicidade dos radicais de oxigênio. Estes radicais podem interagir com o peróxido de hidrogênio ou com peróxidos orgânicos ocorrendo processos altamente reativos que podem atacar o DNA, membranas lipídicas e outros componentes celulares essenciais. $\mathrm{O}$ autor discorreu ainda, sobre os mecanismos de defesa biológicos naturais existentes para prevenir danos às células.

ISQUIERDO $^{48}$, em 1979, avaliando as diferenças entre o tratamento contínuo e descontínuo com o DMBA, utilizou 160 hamsters sírios dourados divididos em 2 grupos e o tratamento realizado três vezes por semana na bolsa da bochecha de hamster. O grupo 1 recebeu tratamento contínuo com a droga por 8 semanas e, o grupo 2 recebeu tratamento descontínuo (duas semanas de aplicação, uma de descanso, três de aplicação, uma de descanso e três de aplicação). Foi utilizado um grupo controle de 80 hamsters. A observação dos animais foi realizada até a sua morte, quando se realizou as necropsias para verificar metástases. A partir da $8^{\mathrm{a}}$ semana de tratamento, os animais desenvolveram 
neoplasias em ambos os grupos. O grupo 1 passou por fases de inflamação, úlcera, reparo e tumor. O grupo 2, após inflamação, apresentou regeneração na semana de descanso e reparo. Cerca de $80 \%$ dos animais tratados apresentaram carcinomas espinocelulares em foco único, ou múltiplo, na área da aplicação. Ao final de 2 meses, a sobrevida foi de 90\%; e diminuiu para 60\%, aos 4 meses; e, $30 \%$ aos 6 meses. Na necropsia, houve o aparecimento de $50 \%$ dos casos de neoplasia abdominal (linfoma) e ausência de metástases. O autor concluiu que com a utilização dessa técnica existe uma grande simplificação na aplicação de carcinógenos, reduzindo então, tempo e trabalho.

NELSON $^{68}$, em 1981, em uma apresentação na American Cancer Society National Conference on Cancer Prevention and Detection, Chicago, 1980, fez uma análise sobre o crescimento de substâncias químicas industriais às quais o ser humano se expõe diariamente, no meio ambiente, seja trabalhando nas indústrias, seja pelo contato com os alimentos através dos aditivos, seja na poluição do ar, seja na radiação solar e até mesmo através da contaminação com poluentes orgânicos no tratamento da água, sendo que a maioria dessas substâncias são carcinogênicas ou co-carcinogênicas. Como conclusão, ele fez um alerta: que a exposição ao meio ambiente e o contato com substâncias, principalmente, as químicas, favorecem o aumento da ocorrência de câncer nos seres humanos.

Em um trabalho de revisão, em 1981, MILLER; MILLER ${ }^{65}$, realizaram uma ampla abordagem sobre os mecanismos da carcinogênese, suas causas possíveis e discutem sobre os agentes etiológicos, principalmente os químicos, no desenvolvimento do câncer. Neste trabalho, enfocaram também os múltiplos estágios da carcinogênese e 
suas reações químicas para o desenvolvimento do câncer. Como prevenção sugerem uma exposição menor aos fatores químicos que existem em nosso meio já conhecidos como carcinogênicos.

EVESON; MACDONALD ${ }^{25}$ em 1981, avaliaram o desenvolvimento de neoplasias na mucosa ventral da lingua de hâmsters, por considerarem que os resultados são os que mais se aproximam anatômica e estruturalmente dos carcinomas na espécie humana. Utilizaram 40 hamsters sírios dourados com idades que variaram entre 8-10 semanas e foram divididos em 3 grupos. Os animais receberam a aplicação do DMBA 0,5\% em acetona, na mucosa ventral lingual, por 28 semanas. O grupo 1 , contendo 20 animais, recebeu o DMBA 0,5\% em acetona e escarificação prévia; o grupo 2, com 10 animais, recebeu a acetona e escarificação prévia; e no grupo 3 também com 10 animais não recebeu nenhum tratamento. Ao final do período experimental, os animais foram sacrificados. Houve o desenvolvimento de tumores em $75 \%$ dos animais tratados após 28 semanas, com papilomas, carcinomas invasivos e sem metástases. Houve uma extensão do tumor para outras áreas próximas à aplicação como freio lingual e assoalho de boca, provavelmente pela maior sensibilidade e pelo contato contínuo com a droga nestes locais. Ulcerações macroscópicas parecem não ser um precursor necessário de malignidade epitelial neste modelo. Os tumores foram precedidos por uma fase semelhante a leucoplasia humana.

FREEMANN; CRAPO $^{29}$, em 1982, realizaram um trabalho de revisão analisando os efeitos dos radicais livres nas células, o seu mecanismo de ação e os sistemas de 
defesa das células. Os autores salientaram que vários agentes ambientais, incluindo poluentes do ar, o fumo, os pesticidas, os solventes e os hidrocarbonetos aromáticos em geral, liberam radicais livres prejudiciais para as células. A presença dos radicais livres nas células são regulados por mecanismos enzimáticos normais de defesa, que atuam para diminuir a quantidade destes radicais presentes nas células, pois em excesso causam danos aos componentes celulares.

ODUKOYA; SHKLAR ${ }^{70}$, em 1982, com a finalidade de avaliar a existência de dois estágios na carcinogênese no modelo de DMBA-indução em hamsters, utilizaram 60 animais divididos em 3 grupos. No Grupo 1, aplicaram três vezes por semana, durante 10 semanas, solução oleosa de DMBA a 0,1\%, sendo controlados por mais 10 semanas; no Grupo 2, aplicaram a mesma solução de DMBA por 10 semanas, interrompendo o procedimento por 6 semanas, quando então uma solução de DMBA a 0,5 \% foi aplicada igualmente na bolsa de bochecha da $16^{\mathrm{a}}$ a $20^{\mathrm{a}}$ semana; no Grupo 3 , os animais não foram tratados até a $16^{\mathrm{a}}$ semana, quando eram iniciadas as aplicações de DMBA a 0,5 \% em óleo mineral. Ao término da $20^{\mathrm{a}}$ semana, todos os animais foram sacrificados e os espécimes teciduais fixados em formalina, incluídos em parafina, cortados e corados em H.E. Os resultados encontrados demonstraram que o Grupo 1 apresentou-se normal, sem alterações teciduais. O grupo 3 apresentou áreas de hiperqueratose e displasia, além de regiões com inflamação crônica e algumas ulcerações e inflamação aguda purulenta, com evidências de carcinoma; no Grupo 2, os animais apresentaram hiperqueratose, numerosas áreas de displasia e carcinoma in situ, além de ocasionais carcinomas epidermóides papilíferos. Os carcinomas mostraram-se bem diferenciados, com formação 
marcante de queratina e uma mínima invasão do tecido conjuntivo subjacente. Estes achados demonstram a provável existência de uma fase de iniciação por um carcinógeno em baixa concentração. Nesta iniciação, existe alguma alteração celular, mas não visível à microscopia de luz. Essa presumível alteração celular não desenvolveu neoplasias durante as 10 primeiras semanas subseqüentes a aplicação do DMBA a 0,1\%, mas uma segunda série de aplicação de DMBA a $0,5 \%$ produziu carcinomas no grupo 2, provavelmente pelo papel promotor do mesmo, confirmando assim o conceito de que há duas fases na carcinogênese química.

ODUKOYA; SHKLAR ${ }^{69}$, em 1984, estudaram as fases de iniciação e promoção da carcinogênese bucal em modelo experimental. Uma dose inicial de DMBA a 0,1\% em óleo mineral, aplicada na bolsa bucal de hamster, três vezes por semana, por 10 semanas, após 25 semanas, não resultou no desenvolvimento de carcinomas. Todavia, quando a dose inicial de DMBA era seguida de um período de seis semanas, sem tratamento, após o qual foi aplicado o peróxido de benzoil a $40 \%$, por mais seis semanas, ocorreu um rápido desenvolvimento de carcinoma epidermóide. O peróxido de benzoil e seu solvente acetona não são carcinogênicos diretos. Assim, a solução de peróxido de benzoil a 40\% em acetona, agiu como promotor de DMBA, na carcinogênese, na bolsa bucal de hamster.

AUTIAN $^{3}$, em 1984, fez uma abrangente avaliação do potencial carcinogênico dos metais, componentes químicos e afirmou que muitas vezes não é a substância química original que causa o tumor mas os metabólitos dos seus componentes. Em seu trabalho, cita alguns metais como berílio, níquel, cromo, arsênico, zinco, selênio, 
mercúrio e comenta a utilização destes metais em nosso dia-a-dia de forma direta ou indireta e que estes metais são carcinogênicos ou sugerem carcinogenicidade.

MAREFAT $^{60}$, em 1985, com o objetivo de desenvolver displasias e neoplasias sem a escarificação prévia da língua no modelo DMBA, utilizou 40 hamsters sírios consanguíneos, divididos em 4 grupos de 10 animais. Os grupos receberam aplicações de DMBA em acetona $0,5 \%$, na porção do terço médio lateral da língua, 3 vezes por semana. O grupo 1 recebeu a aplicação do DMBA, por 4 semanas; o grupo 2 recebeu por 6 semanas; o grupo 3 por 8 semanas e o grupo 4 como controle. Como resultado observou que, no grupo 1, 3 animais desenvolveram mudanças displásicas; no grupo 2, 1 animal desenvolveu displasia em duas semanas e 5 desenvolveram carcinomas evidentes; no grupo 3, displasias eram evidentes em 2 animais e carcinomas em 4 animais; o grupo 4 se manteve normal durante o experimento. Como conclusão, constatou que: a) displasias e carcinomas podem ser induzidos em hamsters sírios pela aplicacão local de DMBA sem escarificação prévia; b) displasia lingual pode ser induzida pela aplicação de DMBA em 4 semanas; c) nas condições deste experimento pôde-se induzir neoplasia em 6-8 semanas com aplicação de DMBA, conseguindo resultados positivos em espaços de tempo semelhantes àqueles observados em grupos escarificados.

CANTONI; MURRAY; MEYN ${ }^{13}$, em 1986, avaliaram a citotoxidade do peróxido de hidrogênio sobre o DNA. Utilizando meio de cultura de células de ovário de hamster, os autores verificaram a ocorrência de uma simples quebra nas cadeias do DNA, induzida pelo radical $\mathrm{OH}^{-}$, o que não representou necessariamente nenhuma lesão fatal à célula devido aos seus eficientes e rápidos processos de reparo. Entretanto, quando 
ocorreu uma interferência nestes mecanismos reparadores, neste caso representado por um inibidor enzimático (3-aminobenzidamida), eles observaram a influência neste processo, denotando na fixação da lesão. Apesar dos resultados encontrados evidenciarem um efeito citotóxico do $\mathrm{H}_{2} \mathrm{O}_{2}$ sobre o DNA, outras formas de danos celulares também devem ser consideradas como, por exemplo, a peroxidação dos lipídeos e a destruição das membranas de fosfolipídeos que contribuem decisivamente para a morte celular.

MILNER $^{66}$, em 1986, em um trabalho de revisão analisou a ação dos antioxidantes na dieta e suas reações como inibidores da carcinogênese. Segundo o autor, a ingestão de determinados alimentos pode influenciar a probabilidade de certos tipos de câncer e que não é possível especificar uma dieta com nutrientes que proteja todas as pessoas. Algumas pesquisas indicam que nutrientes como vitamina A, E, C, antioxidantes sintéticos e selênio podem diminuir a susceptibilidade ao câncer através de alterações enzimáticas ou inibindo a fase de promoção.

CARLSSON $^{14}$, em 1987, descreveu alguns mecanismos de defesa do organismo contra os radicais livres principalmente a hidroxila. Segundo o autor, na cavidade bucal, a peroxidase salivar atuaria como um mecanismo capaz de neutralizar a toxicidade do peróxido de hidrogênio protegendo as células das glândulas salivares e do epitélio bucal. Além disso, afirma que o peróxido é produzido em grande quantidade na cavidade bucal, quer durante a produção normal da saliva quer nas colonizações de bactérias da microbiota normal. Nas células e tecidos vivos, o peróxido de hidrogênio sofre uma 
reação de redução dando origem a radicais hidroxilas, extremamente tóxicos e reativos. Quando esses radicais são gerados nos tecidos e células, as conseqüências podem ser devastadoras devido à subseqüente oxidação dos seus componentes vitais como o DNA, membranas lipídicas e proteínas.

KONDO; TSUCHIKAWA; KATO ${ }^{53}$, em 1987, com o objetivo de avaliar o processo de indução química de carcinoma em duas fases, foram aplicadas duas concentrações diferentes de DMBA em parafina líquida, $0,1 \%$ e $0,5 \%$, na bolsa bucal de hamster. O DMBA a $0,1 \%$, pincelado continuamente por 22 semanas não induziu nenhum carcinoma. Num experimento preliminar, observaram que o DMBA a 0,5\% produziu carcinomas de células escamosas após aplicações durante 12 semanas. No entanto, na aplicação do DMBA a $0,5 \%$, por 6 semanas, precedida pela aplicação do DMBA a $0,1 \%$, por 10 semanas, houve o mesmo resultado. Desta forma, a aplicação do DMBA a $0,5 \%$ por 6 semanas tem a função de promotor. Nem a aplicação do DMBA a 0,1\%, por 10 semanas, nem a aplicação do DMBA a 0,5\% por 6 semanas produziram carcinomas; pelo contrário, com a aplicação do DMBA a 0,5\%, por 6 semanas seguida da aplicação do DMBA a $0,1 \%$, por 10 semanas, não ocorreu indução de carcinomas. A parafina líquida não apresentou nem ação iniciadora, nem promotora. O período de intervalo entre a aplicação do DMBA a 0,1\%, por 10 semanas, e a aplicação do DMBA a $0,1 \%$, por 6 semanas, como iniciação, não foi reversível pelo menos por 8 semanas de aplicação. Com os resultados desse trabalho ficou evidente a existência de duas fases para a carcinogênese bucal. 
Em um recente Projeto de Expansão da Prevenção e Controle do Câncer de Boca $^{82}$ desenvolvido pelo Programa de Oncologia - PRO-ONCO numa ação conjunta do Ministério da Saúde e do Ministério da Previdência e Assistência Social, estabeleceramse, em 1988, uma meta a ser atingida em 5 anos, definindo as áreas prioritárias, a política e as ações a serem desenvolvidas na prevenção e diagnóstico precoce de câncer bucal. Segundo o levantamento realizado, o câncer bucal corresponde a 8,5\% dos casos registrados no sexo masculino e 2,3\% nas mulheres. Em relação ao estadiamento de pacientes com câncer de boca constataram que, ao serem atendidos pela primeira vez em serviços especializados, mais de $80 \%$ dos casos estavam em fase avançada da doença. Dos 13.000 diagnósticos notificados ao INCA, apenas 342 casos foram detectados por profissionais da Odontologia o que representa 2,6\%. Segundo os autores este fato é lamentável, pois os dentistas, a quem compete detectar este tipo de neoplasia aproveitam muito pouco esta oportunidade de diagnosticar as lesões iniciais, quando ainda existe possibilidade de cura. Em relação às regiões geográficas, a Região Nordeste apresentou os maiores índices de câncer de boca no Brasil. Os autores comentaram ainda, que no país, observa-se a existência simultânea de doenças ligadas ao subdesenvolvimento e aquelas relacionadas ao processo de industrialização e suas conseqüentes agressões ao meio ambiente e ao homem.

BLOT et al. ${ }^{11}$, em 1988, com o objetivo de avaliar a incidência de câncer bucal e faríngeo conduziram um estudo com 1114 pacientes que faziam uso de álcool e tabaco e 1268 pacientes controle. Como resultado observaram que pacientes fumantes que ingerem bebidas alcoólicas têm alto índice de desenvolvimento de câncer bucal, com maior freqüencia pela região da língua do que em outra área da cavidade bucal e 
faríngica. O álcool e o fumo combinados são fatores desencadeantes de cânceres, ou seja, uma substância aumenta o potencial da outra. O álcool seria o promotor e o fumo o iniciador da carcinogênese. Observaram ainda que as pessoas que utilizam as duas substâncias correm alto risco de desenvolverem câncer bucal e faríngeo.

JOVANOVIC et al. ${ }^{50}$, em 1991, em um estudo longitudinal, avaliaram 690 consumidores de álcool e usuários de tabaco no intuito de verificarem se estes hábitos são fatores determinantes no surgimento de carcinoma bucal e avaliaram em qual região da cavidade bucal a incidência é maior. Os grupos foram divididos em fumantes moderados (1 a 20 cigarros por dia), fumantes inveterados (mais de 20 cigarros por dia), consumidores de álcool moderado (4 unidades por dia), alto consumo (mais de 4 unidades por dia). O álcool foi dividido em unidade, equivalente a $10 \mathrm{~g}$ de álcool por dia e as bebidas testadas foram vinho, licor ou cerveja. Estes grupos foram contrastados com não usuários de álcool e tabaco. Como resultado observaram que usuários de álcool e tabaco desenvolveram carcinomas em várias regiões da cavidade bucal e lábio. A região de maior incidência de carcinoma foi o assoalho da boca, a área retromolar com maior incidência, seguida de outras regiões, tais como: o lábio inferior e o palato.

LARSSON $^{56}$, em 1991, relatou brevemente as teorias para a indução química tumoral, objetivando esclarecer e incentivar as investigações dos efeitos adversos dos vários tipos de materiais odontológicos. A carcinogênese origina-se a partir de uma única célula que, após percorrer estágios mutagênicos definidos, denominados de iniciação, promoção e progressão dão origem a clones celulares que desenvolvem, irreversivelmente, um tumor. $\mathrm{O}$ autor salientou também que, diante de dúvidas sobre o 
potencial de risco à saúde do paciente, pelos produtos químicos liberados dos materiais odontológicos, dever-se-iam realizar testes para averiguação destes potenciais para serem utilizados com segurança.

COHEN; ELLWEIN ${ }^{18}$, em 1991, abordaram os mecanismos da carcinogênese, os riscos de exposição a agentes químicos, as possibilidades de erros genéticos nas células levando ao desenvolvimento do câncer e todos os fatores que associados aumentam o risco ao câncer. Os autores discutiram ainda, os mecanismos de proliferação celular e a sua ligação com o câncer; e também descreveram a classificação dos agentes químicos que podem ser: genotóxico, onde ocorre alteração do DNA e os epigenéticos ou não genotóxicos que possuem ação de forma indireta.

ROBBINS; COTRAN; KUMAR ${ }^{77}$, em 1991, fez uma abrangente descrição sobre neoplasias, os agentes carcinogênicos e suas interações celulares. Descreveu sobre as etapas da carcinogênese química, bem como as substâncias químicas carcinógenas. O autor definiu um agente co-carcinogênico como aquele que tem a capacidade de induzir tumores em células iniciadas, porém por si só, não são tumorogênicos; e provavelmente os promotores não afetam diretamente o DNA. Algumas substâncias químicas possuem a capacidade tanto de iniciação quanto de promoção, como os hidrocarbonetos aromáticos, por exemplo, evidenciado por sua habilidade de induzir tumores, sem o acréscimo de quaisquer outros fatores, são os carcinógenos completos. As células iniciadas são suscetíveis à ação dos promotores e dão origem a tumores, quando estimuladas, devidamente pelos agentes promotores. 
HOWARD $^{45}$, em 1992, avaliou as reações adversas de dois clareadores utilizados na técnica caseira. Um total de 32 pacientes foram instruídos a utilizar as substâncias durante 6 semanas. Os resultados demonstraram que as reações adversas variaram desde o paladar desagradável das substâncias (26,66\%), queimaduras no palato $(26,66 \%)$, garganta $(20 \%)$ e gengiva $(16,66 \%)$ a sensibilidade dentária $(16,66 \%)$ e até ulcerações gengivais $(3,33 \%)$. Apesar de presentes, todos os efeitos foram considerados temporários e reversíveis. Contudo novos estudos a longo prazo foram sugeridos para a completa avaliação dos peróxidos. O autor salienta também a reclassificação dos clareadores realizado pela FDA.

Em um trabalho, de 1992, elaborado como parte de um documento global sobre Saúde e Meio Ambiente da Fundação Oswaldo Cruz, LOPES et al. ${ }^{59}$, fizeram uma análise sobre o os agrotóxicos, as radiações, seja solar ou ionizante, e também sobre os fatores ligados à dieta na etiologia do câncer, tais como: conservantes, aromatizantes, corantes, estabilizantes, antioxidantes ou tóxicos naturais: micotoxinas e microorganismos. O trabalho relatou fatores da dieta que podem aumentar o risco de câncer, como: gordura, compostos nitrosos, defumados, alimentos quentes, tais como: o café e o chá, micotoxinas, pesticidas, embalagens dos alimentos, enfim, inúmeras substâncias com as quais estamos em contato direto em nosso meio e que estão relacionadas ao desenvolvimento de câncer. $\mathrm{O}$ estudo enfocou também os fatores da dieta que podem reduzir o risco de câncer como é o caso dos antioxidantes e, que existem muitas substâncias que suprimem várias etapas do processo carcinogênico. No entanto, alguns dados indicam que a dieta alimentar do brasileiro ainda está deficiente quanto às 
quantidades necessárias de ingestão dessas substâncias, para a prevenção de alguns cânceres.

BLOT $^{10}$, em 1992, comentou estudos epidemiológicos sobre álcool e câncer enfocando as características desta associação e discutiu os caminhos pelos quais as bebidas alcoólicas podem causar vários tipos de cânceres, principalmente na cavidade bucal. Descreveu ainda, algumas hipóteses que podem esclarecer os mecanismos que levam o álcool a causar câncer; são elas: - o álcool ou bebidas alcoólicas podem conter componentes que possuem efeitos carcinogênicos, como é o caso do N-nitroso (em algumas cervejas), micotoxinas (em alguns vinhos), uretano, resíduos de pesticidas ou arsênico inorgânico e também os espessantes, aromatizantes, conservantes, aldeídos, fenóis e acetona, todas estas substâncias podem influenciar no processo carcinogênico; os metabólitos podem ser carcinogênicos, no caso do álcool o maior metabólito do etanol é o acetaldeído que possui propriedades de carcinógeno; - o álcool provoca uma deficiência nutricional que pode alterar a função e a química das células epiteliais aumentando a susceptibilidade aos carcinógenos; - os hormônios podem ter os níveis, as funções e o metabolismo alterados pela influência do álcool; - a associação do álcool com o fumo elevam os índices tumorais na cavidade bucal. Uma proporção de $75 \%$ dos cânceres na cavidade bucal nos Estados Unidos ocorrem da associação do álcool e do fumo ocasionados pelo efeito sinérgico entre as duas substâncias; - existe uma sugestão de que os anti-sépticos bucais que contenham níveis elevados de álcool possam influenciar na carcinogênese bucal mais pelo uso tópico do que pela via sistêmica. 
HIGGINSON $^{42}$, em 1992, comenta alguns aspectos quanto à ação dos carcinógenos químicos na população humana. A International Agency for Research on Cancer considerou como carcinogênicos químicos para o homem produtos como: o fumo, o álcool, a dieta, os aditivos alimentares, a poluição e os produtos industriais. Cerca de $80 \%$ dos cânceres humanos são de origem ambiental, sendo suas causas atribuídas aos mais variados fatores do meio ambiente. Segundo o autor, evidências sugerem que $25 \%$ a $50 \%$ dos cânceres no Ocidente são influenciados por constituintes naturais da dieta e por químicos que são produtos celulares normais ou metabólitos.

Em um trabalho realizado no Serviço de Epidemiologia da Coordenadoria de Programas de Controle de Câncer no Instituto Nacional do Câncer, MENDONÇA ${ }^{63}$, em 1992, fez uma análise da ocorrência de câncer no Brasil e discute os principais fatores de risco para o desenvolvimento do câncer. Entre eles temos os que estão no meio ambiente, tais como: os químicos, o vírus (hepatite B), as radiações, os componentes alimentares, o fumo, a dieta, o álcool. O autor concluiu que o aparecimento do câncer não é um fator isolado, mas a interação de fatores de risco que existem em nosso meio e que a população está cada vez mais exposta a agentes cancerígenos ocupacionais e ambientais. As possibilidades para se fazer a prevenção dos diversos tipos de câncer só terão êxito, quando se considerar esta complexidade etiológica que envolve o desenvolvimento do câncer.

BARRETTO $\mathrm{NETTO}^{7}$, em 1992, definiu Patologia ambiental como sendo distúrbios causados no organismo pela sua exposição a agentes externos presentes no ar 
poluído, no ambiente industrial contaminado por substâncias químicas de elevado potencial tóxico e pelo uso indiscriminado dos chamados defensivos agrícolas. O autor entre outros pontos, enfatizou sobre o mecanismo geral de ações das substâncias tóxicas, tais como: a dissolução das membranas das células, a desnaturação de proteínas e as alterações enzimáticas; também sobre os agentes químicos carcinogênicos como poluição do ar, efeitos do fumo, poluição industrial, aditivos alimentares, pesticidas e micotoxinas.

RODRIGUES; CAMARGO ${ }^{76}$, em 1992, descreveram sobre a carcinogênese química e suas múltiplas etapas. Afirmando, que estudos experimentais in vivo e in vitro, demonstram que fatores variados da natureza, tais como: agentes químicos, físicos e biológicos são capazes de induzir transformação neoplásica. Os autores acreditam que em condições naturais a transformação neoplásica resulta da confluência de múltiplos fatores.

RUBIN; FARBER ${ }^{78}$, em 1992, fizeram uma descrição sobre carcinogênese química definindo como um processo de múltiplas etapas onde os estágios podem ser divididos em iniciação, promoção, progressão e manifestação clínica da lesão. Descreveram entre outros pontos, os fatores que influenciam a carcinogênese química, tais como: hormônios, dieta, químicos promotores ou iniciadores.

FASSONI et al. ${ }^{27}$, em 1993, objetivando padronizar uma metodologia eficaz para o estudo da carcinogênese bucal química, utilizaram 120 hamsters sírios dourados, divididos em 4 grupos experimentais de 30 animais. O grupo I foi considerado controle e 
não recebeu nenhum tratamento; o grupo II recebeu acetona; o grupo III recebeu o DMBA a 0,5\% diluído em acetona; no grupo IV foi realizada uma escarificação prévia para em seguida receber o DMBA a 0,5\% diluído em acetona. Os animais receberam a droga 3 vezes por semana, pincelada na porção média da borda lateral lingual. Cada grupo foi dividido em 3 períodos experimentais de 7, 13 e 20 semanas. Como resultado o DMBA produziu lesões cancerizáveis e carcinomas passíveis de serem acompanhados macro e microscopicamente em vários períodos experimentais a serem estabelecidos. Os carcinomas DMBA-induzidos não constituem modelo experimental adequado para se avaliar o potencial metastático, pois não se mostrou eficaz quanto a sua frequiência e grau de comprometimento, no período de observação avaliado. Observaram ainda que, o modelo experimental de indução química de carcinoma pela aplicação de DMBA a 0,5\% em acetona, na porção média da borda lateral lingual de hamsters, sem escarificação prévia, constitui uma metodologia simples e eficaz para utilização como controle positivo em testes com outras drogas ou fatores carcinogênicos locais ou sistêmicos.

CAMARGO, et al. ${ }^{12}$, apresentaram um trabalho em 1993 sobre os testes para detecção de cancerígenos químicos e destacaram as vantagens de se adotar testes de curta duração para avaliar as substâncias químicas existentes em nosso meio. Os autores comentaram que no Brasil não há condições para se fazer os testes existentes que são de longa duração, pois falta infra-estrutura e pessoal especializado. Como o aumento de substâncias químicas de origem industrial passaram a representar de 1-8\% das neoplasias humanas, tornou-se necessário que os governos de cada país regulamentassem a sua produção, seu uso, distribuição e a eliminação destes agentes químicos, potencialmente 
cancerígenos, em benefício da população. Para isso existem dois tipos de estudo: os clínicos - epidemiológicos e os experimentais em roedores. Quando um agente cancerígeno é detectado pelos estudos epidemiológicos significa que a população já se comprometera com o efeito nocivo da substância. Desta forma, os testes experimentais em roedores são os mais apropriados, aos quais os agentes químicos devem ser submetidos antes de entrar em contato com qualquer utilização em humanos. Apenas os testes de mutagenicidade não são suficientes para comprovar a carcinogenicidade das substâncias, pois cerca de 25\%-30\% destas substâncias cancerígenas não têm potencial mutagênico (alterar o DNA diretamente) e não são detectáveis pelos testes de mutagenicidade. No entanto, são potentes carcinógenos que atuam nas células indiretamente pela proliferação celular, são denominados agentes não-genotóxicos. Os autores enfocaram ainda a dificuldade, no Brasil, de se fazer os testes de longa duração, devido ao alto custo e que muitas substâncias estão à espera de análise.

SALLES et al. ${ }^{79}$, em 1994, avaliaram o potencial carcinogênico do formocresol diluído a $1 / 5$ e do glutaraldeído a $2 \%$ no modelo de DMBA-indução. Foram utilizados 180 hamsters sírios dourados divididos em 6 grupos experimentais com 30 espécimes cada. O grupo I e II foram considerados controles. O grupo I recebeu o DMBA diluído em acetona a 0,5\%; o grupo II somente o solvente do carcinógeno, ou seja, a acetona; o grupo III recebeu a aplicação do formocresol diluído a 1/5; e o grupo IV, por sua vez, foi submetido ao mesmo tratamento, porém, precedido de trauma por escarificação. Os grupos V e VI foram tratados com glutaraldeído a $2 \%$ sem e com escarificação prévia respectivamente. Os animais receberam a aplicação da droga 3 vezes por semana na 
porção média lateral lingual. Cada grupo foi dividido em 3 períodos experimentais de 7, 13 e 20 semanas, com 10 animais. Obtiveram como resultados que o formocresol diluído a $1 / 5$ e o glutaraldeído a $2 \%$ induzem alterações epiteliais hiperplásicas nos locais das aplicações, mas sem modificações morfológicas que caracterizem displasia epitelial. Não houve indução à formação de papilomas e carcinomas nos animais em que foram aplicados formocresol diluído a 1/5 e glutaraldeído a 2\%, na mucosa da borda lateral da língua de hamster, tal como ocorreu com o DMBA a 0,5\%. Desta forma, o formocresol diluído a $1 / 5$ e o glutaraldeído a $2 \%$, quando comparados ao DMBA a 0,5\% no mesmo método de aplicação, não são carcinógenos completos. 
2 - Peróxidos

O peróxido de carbamida pode ser encontrado em concentrações de $10 \%, 11 \%$, $15 \%, 16 \%$ e $35 \%$ em anidro glicerol ou glicerina, $\left(\mathrm{CH} 4 \mathrm{~N}_{2} \mathrm{O}-\mathrm{H}_{2} \mathrm{O}_{2}\right)^{23,26,54,62}$ é conhecido como, peróxido de uréia, peróxido de hidrogênio uréia, peróxido de hidrogênio carbamida ou peridrol-uréia; utilizados na técnica caseira de clareamento dos dentes vitalizados $^{21,26,39,40,41,84,90}$. São substâncias instáveis e quando em contato com a saliva se dissociam em $3,6 \%$ - 5\% de peróxido de hidrogênio e 6,4\% - 7\% em uréia ${ }^{26,41,46,71}$. O peróxido de hidrogênio por sua vez, se dissocia em oxigênio e água, quebrando-se posteriormente e liberando os radicais livres; a uréia dissocia-se em amônia e dióxido de carbono $^{1,26,38,39,40}$.

O peróxido de hidrogênio é o ingrediente ativo do peróxido de carbamida. A presença destes radicais livres originários da quebra do peróxido de hidrogênio é preocupante pelo fato de que, esses radicais $\mathrm{O}_{2}$ (ânions superóxidos) e $\mathrm{OH}^{-}$(íons hidroxila), são radicais oxidantes altamente reativos e tóxicos que agem diretamente nos componentes vitais das células, onde danificam membranas celulares, alteram o DNA, as proteínas, podendo causar mutações ${ }^{15,47,73}$. Sabe-se, porém que o organismo possui mecanismos de defesa bioquímicos e reparos intracelulares que reagem com os radicais livres para inativá-los como é o caso do sistema enzimático ${ }^{30}$. Entretanto, este mecanismo pode sofrer interferências no processo de reparo, causando alterações e possivelmente permitindo a fixação da lesão na célula ${ }^{13,47}$. Em relação ao pH desses clareadores sabe-se que fica em torno de 4,6 a 7,4, $4^{1,6,21,23,26,40,57,58}$. O peróxido de carbamida se divide em duas 
categorias quanto à presença ou ausência de carbopol, um polímero de carboxipolimetileno ou uma base de glicerol, Carbomer 940. O carbopol é um polímero solúvel em água com alto peso molecular e funciona como um espessante utilizado para estabilizar o processo de dissociação do clareador, além de liberar o oxigênio nascente de maneira mais lenta e aumentar a aderência do produto à estrutura dentária pela sua viscosidade $^{1,5,22,23,38,39,41,72}$.

A seguir enfocaremos alguns trabalhos sobre a citotoxicidade e efeitos mutagênicos dos peróxidos, e também quanto à regulamentação destes produtos como clareadores caseiros.

GIUSTI $^{35}$, em 1973, relatou um caso de ingestão fatal de peróxido de hidrogênio a 30\%-35\% por uma criança de um ano de idade. A criança morreu uma hora após a ingestão por falha respiratória e apresentando distensão do abdômen. $\mathrm{O}$ exame histológico demonstrou na mucosa do estômago, duodeno e esôfago evidências de necrose. $\mathrm{O}$ autor salientou que a ingestão de $3 \%$ a $9 \%$ pode causar irritação na membrana da mucosa gástrica e uma média distensão abdominal.

ITO et al. ${ }^{49}$, em 1981, avaliaram a indução de tumores duodenais em ratos pela administração de peróxido de hidrogênio. Os animais foram divididos em 3 grupos de 100 onde a solução de peróxido de hidrogênio foi adicionada na água destilada para beber, com diluição de $0,4 \%, 0,1 \%$ e $0 \%$. No início do estudo, os animais tinham 8 semanas de idade e o experimento foi até os animais completarem 108 semanas de idade. 
Como resultado: os grupos de $0,4 \%$ e $0,1 \%$ de diluição apresentaram alta incidência de hiperplasia $62 \%$ e $40 \%$ respectivamente. Adenoma duodenal foi encontrado em $5 \%$, no grupo de $0,4 \%$ de diluição, e, $1 \%$ no grupo de $0,1 \%$ de diluição. Erosões gástricas apareceram em 40 semanas, hiperplasia duodenal em 10 semanas e carcinomas duodenais em 65 semanas. Os autores concluíram que o peróxido de hidrogênio pode ter dupla função na formação de nódulos duodenais; ampliação de ocorrência espontânea de hiperplasia duodenal e transformação de nódulos hiperplásicos em neoplásicos.

HIROTA; YOKOYAMA ${ }^{43}$, também em 1981, observaram o efeito potencializador do peróxido de hidrogênio sobre carcinogênese duodenal e na parte alta do jejuno na carcinogênese em ratos. Os animais foram divididos em quatro grupos. $\mathrm{O}$ grupo I e II receberam injeção de acetato (methylazoxymethanol - MAN), um potente carcinógeno, intraperitoneal começando com idade de 12 semanas com uma dose de 25 $\mathrm{mg} / \mathrm{Kg}, 3$ vezes, uma vez a cada 2 semanas. A água com o peróxido foi administrada durante todo o tempo da injeção, exceto 2 dias de intervalo seguindo a cada injeção, quando foi dada a água de torneira. No grupo I, a água com peróxido foi dada continuamente durante o experimento; no Grupo II, foi descontinuada e os animais foram mudados para água de torneira; no Grupo III, recebeu água com peróxido durante todo o experimento; no Grupo IV, foi tratado como controle. Os animais foram sacrificados com 29 semanas e foi dada particular atenção às alterações intestinais. Como resultado obtiveram tumores na parte superior do jejuno e no duodeno com incidência maior no Grupo I do que no Grupo II. Histologicamente todos os tumores foram diagnosticados como adenocarcinomas (mucoso ou invasivo). No Grupo I, 100\% dos animais 
apresentaram adenocarcinomas em contraste com o Grupo II que apresentaram $25 \%$. A carcinogênese tanto no duodeno como no jejuno foi mais pronunciada no Grupo I. Nenhuma alteração neoplásica foi encontrada nos Grupos III e IV, mas; no grupo III apareceu hiperplasia epitelial tanto no duodeno como no jejuno. Uma incidência maior de carcinoma duodenal foi encontrada em animais que foram tratados continuamente com peróxido de hidrogênio por 13 semanas até o término, seguindo a administração do MAN, em comparação com os animais que não receberam por longo tempo o peróxido, na água, depois deste tratamento. Os dados desse trabalho sugeriram que, a administração prolongada de peróxido de hidrogênio aumentou os efeitos carcinogênicos nos ratos tratados com o carcinógeno MAN.

WEITZMAN et al. ${ }^{93}$, em 1984, discutiram a possibilidade dos metabólitos do peróxido de hidrogênio danificar o DNA das células e causar mutações. Os autores alertaram para a administração crônica do peróxido de hidrogênio no tratamento de doenças gengivais, pois a exposição constante pode levar à alterações indesejáveis nos tecidos. As células são danificadas quando expostas a altas concentrações de oxidantes. A preocupação é que os peróxidos podem aumentar a expressão de tumores por outros carcinógenos do meio ambiente. O tumor para se manifestar pode demorar anos ou décadas nos humanos e outros estudos sugerem que metabólitos de oxigênio podem produzir câncer em animais e homens. Como conclusão os autores sugeriram que estudos devam ser realizados antes da população fazer uso desta substância. 
Em 1986, WEITZMAN et al. ${ }^{93}$, desenvolveram um trabalho com o objetivo de avaliar o efeito carcinogênico do peróxido de hidrogênio no modelo de carcinogênese química bucal induzida em hâmster. Os animais foram divididos em 4 grupos, sendo que o grupo I recebeu DMBA; o grupo II recebeu DMBA e peróxido de hidrogênio 3\%; o grupo III recebeu DMBA e peróxido de hidrogênio a 30\%; o grupo IV recebeu peróxido de hidrogênio a 30\%. A concentração do DMBA foi de 0,25\% em óleo mineral. As bolsas da bochecha de hamster foram pinceladas 2 vezes por semana e o sacrifício foi com 19 e 22 semanas. O resultado foi o aparecimento de hiperqueratose e hiperplasia em mais de $85 \%$ dos animais de todos os grupos com 19 semanas. Após 22 semanas, os animais do grupo I apresentaram carcinomas epidermóides em 3 de 7 animais; no grupo II, 6 de 11 animais desenvolveram carcinomas em 22 semanas, e todos os animais do grupo III desenvolveram carcinomas invasivos; no grupo IV, os animais não desenvolveram carcinomas, porém, apresentaram mudanças associadas com lesões préneoplásicas, incluindo hipercromatismo de células e displasia média. Os dados sugeriram uma ação co-carcinogênica do peróxido de hidrogênio no modelo analisado e que sozinho ou associado provocou mudanças pré-neoplásicas e aumentou a atividade mitótica e hiperplásica.

REES; ORTH ${ }^{75}$, em 1986, avaliaram a utilização do peróxido de hidrogênio à 3\% como anti-séptico bucal. Os autores observaram dois casos onde os pacientes fizeram uso da substância diariamente e apresentaram inflamação crônica nos tecidos, lesões na papila, dor ao toque, múltiplas ulcerações na mucosa alveolar e gengiva marginal. A preocupação dos autores está relacionada a altas concentrações de oxidantes que podem 
danificar as células e que o uso crônico de peróxido de hidrogênio pode lesar os tecidos periodontais, além do peróxido funcionar como carcinogênico ou co-carcinogênico se utilizado diariamente por longos períodos. Os autores sugeriram uma reavaliação da utilização desta substância no tratamento periodontal.

BERRY $^{9}$, em 1990, questionou o uso dos clareadores de forma caseira quanto a sua segurança e ressaltou que os cientistas da ADA afirmam que os efeitos nos tecidos a longo prazo são desconhecidos. O peróxido de hidrogênio, liberado na dissociação do peróxido de carbamida quando em contato com a saliva, por sua vez se dissocia nos radicais livres de $\mathrm{O}_{2}$ que são ativos e possuem potencial para causar mudanças celulares. O Conselho Terapêutico da ADA reconheceu que o produto necessita de uma avaliação mais ampla para conhecer os seus efeitos a longo prazo nos tecidos pelas repetidas aplicações do produto. $\mathrm{O}$ autor salientou que os cientistas da ADA não estão inteiramente convictos da utilização dos agentes clareadores caseiros, pois o risco para o uso existe até que se conheça totalmente o seu potencial de ação.

Ainda com relação à ingestão dos agentes clareadores durante o clareamento caseiro, SIMONSEN ${ }^{88}$, em 1990, alertou que o paciente ingere quantidade razoável da substância e que há carência de dados biológicos comprovando a ação tóxica da substância. Ele questionou nesse trabalho os riscos da utilização dessa técnica e sugeriu aos fabricantes que avaliem biologicamente o produto quanto à segurança para não comprometerem o profissional, e não expor os pacientes a um risco desnecessário. $\mathrm{O}$ autor fez uma análise de como os clareadores foram amplamente divulgados sem que se 
conhecessem todos os seus efeitos e que o paciente recebe um tratamento sem saber dos riscos.

LARSON $^{55}$, em 1990, fez uma análise dos efeitos dos peróxidos sobre os dentes, tecidos gengivais e reafirmou a preocupação quanto ao uso de produtos oxidantes como o peróxido de hidrogênio e de carbamida na cavidade bucal. Afirmou ainda que existem evidências de carcinogenicidade em várias concentrações de peróxido de hidrogênio, nos tecidos bucais, e em outros órgãos do corpo humano (estômago, duodeno, pele) e que a presença de radicais livres como seu subproduto aumenta as possibilidades de malignidade. O autor enfatizou que o peróxido de hidrogênio é potencialmente prejudicial ao organismo humano e que não recomenda o uso prolongado, na cavidade bucal, pelos efeitos tóxicos que ocorrem nos tecidos moles.

ANDERSON $^{2}$, em 1991, discutindo as várias técnicas e mecanismos de ação dos clareadores de dentes vitais demonstrou sua preocupação em relação aos peróxidos utilizados na técnica caseira. Segundo o autor, a segurança destes produtos deve ser mais investigada, principalmente, em relação aos possíveis efeitos dos radicais livres de oxigênio liberados nos procedimentos clareadores. As propriedades mutagênicas do material devem ser tratadas com cautela.

CHRISTENSEN ${ }^{16}$, em 1991, em um trabalho de divulgação comentou a aceitação dos clareadores caseiros e que o seu uso de forma imprópria pode danificar tecidos dentais e tecidos moles. O autor salientou que o uso abusivo da técnica de clareamento 
caseiro ocorre pelo tempo de uso excessivo da moldeira, quantidade do material aplicado acima do necessário, excessos que o profissional não têm como acompanhar diariamente. Ressaltou ainda que nenhum clareador recebeu o selo de aceitação pela ADA e que mais pesquisas devem ser feitas para se conhecer suas reações a longo prazo, pois sendo uma técnica recente não se conhece totalmente o seu potencial.

POWELL; BALES ${ }^{73}$, em 1991 avaliando os efeitos dos clareadores nos tecidos constatou inflamação no tecido gengival, provavelmente devido à ação do peróxido de hidrogênio sobre o sistema vascular, aumentando a permeabilidade dos capilares. O peróxido de hidrogênio danifica a membrana externa das células e afeta os seus componentes internos, além de alterar os fibroblastos humanos. Em condições normais, as células possuem um mecanismo de defesa (enzimas) e podem inativar o peróxido de hidrogênio, entretanto estes mecanismos podem falhar se os danos forem grandes. Os autores sugeriram cautela com o uso dos clareadores caseiros até que mais pesquisas sejam realizadas.

DISHMAN; BAUGHAN ${ }^{23}$, em 1992, fizeram um trabalho de revisão sobre os clareadores caseiros, sobre os materiais, técnicas e salientam alguns aspectos importantes sobre a posição da ADA e FDA com relação a estes materiais. Os autores enfatizaram que a partir de uma reavaliação da FDA, esses produtos passaram a ser considerados como drogas e não mais cosméticos. O Conselho Terapêutico da ADA admite que os produtos devem ser melhor avaliados. 
GAGE; FRAZIER; WRIGTH ${ }^{33}$, em 1992, avaliaram a resposta dos clareadores nos tecidos quando aplicados topicamente. Foram utilizados: o peróxido de hidrogênio a $3 \%$, peróxido de carbamida a $10 \%$, glicerina e solução salina como controle. O peróxido de carbamida e o peróxido de hidrogênio desenvolveram severas lesões bucais no epitélio, edemas e petéquias, congestão vascular, infiltrado neutrofílico e ulcerações. O peróxido de hidrogênio se apresentou um pouco mais nocivo topicamente do que o peróxido de carbamida. A glicerina apenas produziu sinais histológicos de inflamação média.

Quanto à ingestão de peróxido de hidrogênio, CHRISTENSEN et al. ${ }^{17}$, em 1992, fizeram um relato clínico de uma ingestão fatal de peróxido de hidrogênio a 35\%, acidentalmente, em uma criança de 2 anos de idade. Observaram na autópsia: dilatação estomacal, gastrite hemorrágica grave, com perfuração gástrica e bolhas no coração. Os autores acreditam que a dose de $3 \%$ de peróxido de hidrogênio é seguro para ser usado em tratamentos caseiros, com um mínimo de toxicidade depois da ingestão porém, embolismo venoso pode ocorrer. Altas concentrações de peróxido de hidrogênio podem causar embolismo no coração e, a morte.

STRASSLER; SCHERER; CALAMIA ${ }^{90}$, em 1992, discutiram a segurança, as indicações e as contra-indicações dos agentes clareadores. Entre outros pontos comentaram sobre a preocupação da ADA e FDA e sobre o uso dos clareadores de forma caseira sem que ainda tenham pesquisas conclusivas sobre sua segurança. Afirmaram que 
as pesquisas clínicas existentes comprovam os efeitos da substância quanto ao tratamento clareador, porém os efeitos nos tecidos ainda não são totalmente conhecidos.

TAM $^{91}$, em 1992, descreveu as técnicas de clareamento caseiro e no consultório, ressaltando os riscos do uso indiscriminado da técnica caseira, a possível ingestão da substância durante o tratamento e dos seus efeitos nos tecidos e células, questionando a segurança do material. A autora relatou também, trabalhos com o peróxido de hidrogênio, verificando seu potencial carcinogênico e a necessidade de se utilizar esta técnica caseira que oferece riscos ao invés de se utilizar com segurança a técnica no consultório.

Com a finalidade de verificar a toxicidade da ingestão do peróxido de carbamida, CHERRY, et al. ${ }^{15}$, em 1993, avaliaram 63 fêmeas de ratos e 3 agentes clareadores. Foram utilizados os clareadores: White \& Brite (10\%), Nu-Smile (15\%) e Quick Start (35\%). As substâncias foram injetadas diretamente no estômago dos animais, onde 9 animais receberam White \& Brite, 9 receberam Nu-Smile e 22 receberam o Quick Start. Como resultado os autores observaram alterações clínicas em todos os grupos, tais como: respiração difícil, cabeça bamboleante, incontinência urinária, crescimento abdominal e fechamento dos olhos. Na necropsia, foi observado um aumento interno do estômago, inchaço e distensão com gás, sangue no interior do estômago e intestino diminuído em quase todos os animais de todos os grupos. Os autores discutiram a ingestão dos clareadores caseiros durante o tratamento. Eles admitiram que podem ser ingeridas quantidades desconhecidas dessas substâncias e que os metabólitos dos clareadores, que são os radicais de hidroxyl e ânions superóxidos, em contato com as células podem produzir alterações nas membranas, danificando o DNA e outros componentes 
intracelulares. Os dados deste trabalho sugeriram que a ingestão dos clareadores avaliados foram altamente tóxicos, e que novos trabalhos devem ser feitos para verificar as doses ingeridas pelos humanos.

GOLDSTEIN; KIREMIDJIAN-SCHUMACHER ${ }^{34}$, em 1993, fizeram uma publicação relacionada ao uso dos clareadores caseiros e aos riscos aos quais os pacientes se expõem para obter benefícios questionáveis, já que os clareadores nem sempre oferecem bons resultados. Os autores enfatizaram os danos que podem ser causados pelo uso prolongado da substância. Relataram que o procedimento é cosmético e não terapêutico e que por isso as agências que regulamentam produtos médicos e dentais não fazem a avaliação desses produtos quanto ao contato com tecidos bucais. Eles citaram que o Conselho Terapêutico da ADA não concede o selo de aceitação desses produtos até que mais pesquisas sejam realizadas. Por outro lado, os produtos são encontrados facilmente no mercado sem que estudos conclusivos tenham esclarecido os efeitos dos clareadores nos tecidos. Os autores enfatizaram que a maior preocupação é o contato dos peróxidos, por um tempo prolongado, com os tecidos moles e que os profissionais não deveriam esperar surgir o problema, para depois resolvê-lo ou seja, os pacientes estão utilizando esses clareadores, sem dados definitivos, quanto à segurança do seu uso. Finalizando os autores comentaram a afirmação da ADA de que os clareadores são efetivos no tratamento clareador, mas questionam qual o custo ou as consequiências desse procedimento.

Em um trabalho de 1994, WANDERA et al. ${ }^{92}$, esclareceram que os clareadores caseiros foram considerados cosméticos pela FDA até 1991. Após essa data, em virtude 
das suspeitas quanto à segurança do seu uso, foram reclassificados como drogas. Em 1992, foram colocados em reexame e os fabricantes continuaram a comercializar os produtos como sendo cosméticos. O FDA classificou o peróxido de carbamida como seguro quando utilizado como anti-sépticos bucais mas, não avaliou quanto ao uso prolongado dos peróxidos como clareadores dentais.

Em uma importante publicação, em 1994, o Conselho Terapêutico Dentário da $\mathrm{ADA}^{20}$ publicou as diretrizes para a aceitação de produtos de higiene oral contendo peróxido de hidrogênio. Essas diretrizes estabelecem que os produtos contenham descrições de todos os ingredientes ativos, com suas respectivas funções e outros detalhes de importância. O Conselho demonstrou uma particular preocupação sobre os efeitos, a longo prazo, dos peróxidos nos tecidos da mucosa e tecidos duros e dos efeitos potenciais genotóxicos da reação do oxigênio. Foram recomendados testes in vitro e in vivo para verificar o potencial genotóxico; quando os resultados desses testes fossem positivos em ambos os sistemas in vitro e in vivo seriam recomendados os testes para verificar o potencial carcinogênico das substâncias no modelo utilizando hamsters. Essa publicação orientou, ainda, o estabelecimento de protocolos de pesquisas clínicas para avaliar os agentes clareadores.

POWERS; FARAH ${ }^{74}$, em 1996, em uma publicação sobre os produtos clareadores e as técnicas usadas discorreram sobre as vantagens e desvantagens de sua utilização. Ressaltaram que existem preocupações sobre o efeito carcinogênico das soluções pela liberação dos radicais livres, durante a dissociação, e que por ser uma técnica recente, 
efeitos a longo prazo são desconhecidos. Os autores sugeriram que o produto seja utilizado com cautela. 


\section{3 - PROPOSIÇÃO}




\section{3 - PROPOSIÇÃO}

A proposta deste trabalho foi analisar comparativamente, as possíveis evoluções macroscópicas e microscópicas das alterações provocadas pela aplicação tópica de dois agentes clareadores à base de peróxido de carbamida a $10 \%$ sobre a mucosa lingual lateral de hamsters sírios dourados, para avaliar o seu potencial carcinogênico no modelo DMBA-indução. 


\section{4 - MATERIAL E MÉTODOS}




\section{4 - MATERIAL E MÉTODOS}

\section{1 - MATERIAL}

\subsection{2 - Amostragem}

A amostra constou de 70 hamsters sírios dourados (Mesocricetus auratus), provenientes do biotério da Faculdade de Medicina da USP, São Paulo. Inicialmente os animais ficaram em observação no biotério do Departamento de Patologia da FOB - USP. Como não correspondiam à idade necessária, entre 60 e 90 dias, os animais livres de qualquer alteração aparente foram cruzados com os hamsters do biotério da FOB-USP, para se obter a amostragem necessária e dentro das especificações exigidas. No início do experimento, os animais apresentaram um peso corporal aproximado de 120 gramas e idade média de 90 dias, sem diferença de distribuição quanto ao sexo e foram alimentados com ração padronizada (Labina - Purina) e água "ad libitum". Durante o experimento, os animais foram mantidos em gaiolas plásticas apropriadas e forradas com papel picado que eram higienizadas diariamente e mantidas em um ambiente arejado e iluminado por luz natural. 


\title{
4.1.2 - Distribuição
}

Os animais foram divididos aleatoriamente em 7 grupos com 10 espécimes cada. O Grupo I recebeu a aplicação de acetona, que é o solvente do carcinógeno, e foi considerado controle do Grupo IV. O Grupo II recebeu a aplicação do peróxido de carbamida 10\% com carbopol (Opalescence ${ }^{\circledR}$, Ultradent Products, Inc.; UP \# 0220), o Grupo III recebeu o peróxido de carbamida a 10\% sem carbopol (White-Brite, Omnii ${ }^{\circledR}$ Inter.; NDC \# 217-3800-60), o Grupo IV recebeu o carcinógeno dimetilbenzantraceno (DMBA), diluído em acetona a 0,5\%. O Grupo V recebeu a aplicação de DMBA + Peróxido de carbamida a 10\% com carbopol; o Grupo VI recebeu DMBA + peróxido de carbamida a $10 \%$ sem carbopol; e o Grupo VII recebeu água destilada, sendo considerado controle geral.

TABELA 1 - Distribuição dos grupos experimentais

\author{
Grupo I - Acetona \\ Grupo II - Peróxido de carbamida à 10\% com carbopol (Opalescence) \\ Grupo III - Peróxido de carbamida à 10\% sem carbopol (White \& Brite) \\ Grupo IV - DMBA \\ Grupo V - DMBA + peróxido de carbamida à $10 \%$ com carbopol \\ Grupo VI - DMBA + peróxido de carbamida à $10 \%$ sem carbopol \\ Grupo VII - Água destilada
}




\subsection{3 - Preparação}

O carcinógeno foi preparado para a obtenção de uma solução na concentração de $0,5 \%{ }^{60,61,67,80}$ diluída em acetona $100 \%^{31,60,80,81}$. O DMBA (ácido dimethilbenzantraceno) utilizado foi obtido na forma de pó (500 mg), pesado em uma balança Mettler P 1000N e diluído em $100 \mathrm{ml}$ de acetona. A solução foi homogeneizada em um agitador magnético

Reverstir, modelo RS-8 (Toyo Kagaku Sangyo, Co., Ltda), por 30 minutos. A solução assim obtida, foi armazenada em vidro de cor âmbar, rotulado de forma apropriada e mantido em temperatura de 4 graus centígrados, no Laboratório de Anatomia Patológica de Departamento de Patologia da Faculdade de Odontologia de Bauru, USP.

As substâncias clareadoras utilizadas nesta pesquisa foram importadas dos EUA e mantidas em geladeira durante todo o experimento no Departamento de Patologia da Faculdade de Odontologia de Bauru -USP.

\section{2 - MÉTODOS}

\subsection{1 - Aplicação}

A aplicação dos agentes químicos foi realizada com a secagem da porção média da borda lateral esquerda da língua com gaze e o pincelamento da superfície da porção média da borda lateral da língua ${ }^{70,78}$ por quatro vezes com pincel pêlo de camelo número zero (Tigre), embebido na solução ou gel. 
O procedimento foi executado para todos os grupos experimentais, três vezes por semana, por um período de 20 semanas $^{48,67,78,80,81}$. Cuidados especiais foram tomados durante a aplicação das drogas, visando a evitar a deglutição das mesmas.

\subsection{2 - Sacrifício dos Animais, Obtenção e Preparação dos Espécimes}

Os animais foram sacrificados por inalação excessiva de éter sulfúrico, em câmara fechada, ao final de 20 semanas. Em seguida, foi executada uma necropsia com retirada da língua, linfonodos regionais, rins, fígado e pulmões. Os órgãos retirados foram fixados em formalina por 24 horas e mantidos em frascos de vidro devidamente etiquetados e identificados. Depois, foram preparados pelo procedimento de rotina até serem incluídos em parafina. Os blocos de parafina foram cortados com 4 micrômetros de espessura, em micrótomo Spencer 820, American Optical Company, com navalhas descartáveis e corados pela técnica de Hematoxilina e Eosina (H.E.).

\subsection{3 - ANÁLISE MACROSCÓPICA}

Os animais foram observados visualmente no transcorrer de todo o experimento e as alterações evolutivas e colaterais foram devidamente anotadas. As modificações macroscópicas observadas foram registradas e classificadas de acordo com sua forma e cor em: Mancha branca, Mancha vermelha, Formação exofitica, Ulceração. 
Além das observações visuais alterações macroscópicas foram fotografadas usando-se uma máquina fotográfica Yashica Dental-Eye e filme Ektachrome Kodak ASA 64 e Kodacolor ASA 100.

\subsection{4 - ANÁLISE MICROSCÓPICA}

Os cortes dos tecidos após serem corados, foram analisados em microscópio Nikon binocular. Após o diagnóstico das alterações observadas, estas foram classificadas e quantificadas em valores numéricos (VN) estabelecidos aleatoriamente em ordem crescente da seguinte maneira:

\subsubsection{1 - Mucosa Normal ( $\mathrm{VN}=1)$}

Toda mucosa bucal do hamster é revestida por epitélio estratificado pavimentoso, que pode se apresentar queratinizado ou não queratinizado, dependendo do local. Em diferentes partes da boca existem variações na estrutura da mucosa refletindo diferenças em suas funções. Na mucosa lingual lateral, o epitélio de revestimento é estratificado pavimentoso e discretamente queratinizado. O estrato granuloso é mínimo e a junção epitélio-conjuntivo, marcada por cristas epiteliais que se projetam em direção à lâmina própria. 


\section{2. 4. 2 - Hiperplasia e Hiperqueratose}

A hiperplasia epitelial foi considerada e diagnosticada quando se observava um aumento significativo do número de camadas epiteliais provenientes de qualquer estrato, especialmente do espinhoso, ultrapassando o número de camadas da mucosa normal da borda lateral da língua de hamster. Normalmente, o epitélio apresenta uma queratinização discreta. Assim sendo, quando ocorria um aumento da paraqueratose ou ortoqueratose, em qualquer intensidade, o diagnóstico era facilmente realizado.

Foram estabelecidas uma subdivisão da hiperplasia e hiperqueratose quanto à presença ou ausência de displasia epitelial.

4. 2. 4. 2. 1 - Hiperplasia e hiperqueratose sem displasia epitelial

A quantificação foi subjetiva quanto ao grau de hiperplasia e hiperqueratose, considerando-as discreta $(\mathrm{VN}=2,0)$, moderada $(\mathrm{VN}=2,4)$ e intensa $(\mathrm{VN}=2,8)$. A classificação final, para cada grupo, correspondeu à mediana dos valores numéricos encontrados para cada animal. 


\section{2. 4.2. 2 - Hiperplasia e hiperqueratose com displasia epitelial}

O diagnóstico de displasia epitelial obedeceu aos critérios recomendados pela Organização Mundial da Saúde - W.H.O ${ }^{95}$ e por KATZ; SHEAR; ALTINI ${ }^{51}$. Estes critérios são os seguintes:

1- Perda da polaridade das células basais;

2- presença de mais de uma camada de células com aspecto basalóide;

3- aumento do índice núcleo/citoplasmático;

4- aumento do número de figuras de mitose;

5- pleomorfismo celular (atipias);

6- hipercromatismo nuclear;

7- nucléolos evidentes;

8- perda ou diminuição da coesão celular;

9- disqueratose (queratinização precoce na estrutura epitelial);

10- cristas epiteliais irregulares;

11- estratificação epitelial irregular;

12- mitose na porção superficial do epitélio;

13- Mitoses atípicas.

As displasias foram classificadas em discreta, moderada e intensa ou carcinoma in situ, de acordo com o grau de comprometimento do epitélio, ou seja, terço basal (VN = $3,0), 2 / 3$ da espessura $(\mathrm{VN}=3,4)$ ou toda a espessura do mesmo $(\mathrm{VN}=3,8)$. 
Para o diagnóstico de displasia epitelial foi considerado essencial a presença concomitante de perda da polaridade das células basais, pleomorfismo celular e mitoses atípicas.

\subsubsection{3 - Carcinoma microinvasivo $(\mathrm{VN}=4)$}

O diagnóstico foi estabelecido quando se observava destruição da membrana basal do epitélio pelas células neoplásicas atípicas com invasão limitada à lâmina própria.

\subsubsection{4 - Carcinoma invasivo sem metástase aparente $(\mathrm{VN}=5)$}

O diagnóstico foi estabelecido pela observação da invasão comprometendo também a submucosa, sem a presença de metástases regionais ou à distância.

\section{2. 4. 5 - Carcinoma invasivo com metástase aparente $(\mathrm{VN}=6)$}

O diagnóstico foi estabelecido quando havia invasão da submucosa associada a metástases nos órgãos dos animais, removidos durante a necropsia. Foram analisadas: a desorganização estrutural, as alterações degenerativas, a presença de infiltrado inflamatório e a ocorrência de neoplasia primária e metastática nos linfonodos, nos rins, no fígado e nos pulmões. 
Os valores numéricos de cada grupo foram estabelecidos calculando-se a sua mediana. Estes valores foram tabulados e analisados pelos métodos de Kruskal Wallis e Mann Whitney para estabelecimento da significância estatística ${ }^{4,87}$. 


\section{5 - RESULTADOS}




\section{5 - RESULTADOS}

\section{1 - ANÁLISE MACROSCÓPICA}

Os dados referentes à análise macroscópica estão representados na Tabela 2 na qual observa-se que, no período de 20 semanas nos grupos I (Acetona) e VII (Água destilada), a normalidade se manteve até o final do experimento. Nos grupos II (Opalescence) e III (White \& Brite), havia uma irritação avermelhada superficial da mucosa. No grupo IV (DMBA), as lesões eram visíveis quando o carcinoma DMBAinduzido estava praticamente instalado. Nos grupos V e VI que receberam o peróxido de carbamida 10\% + DMBA, lesões eram visíveis com formação exofítica; a superfície das lesões possuíam áreas ulceradas e sangrantes ao toque (Figura 5). Lesões papilomatosas apareceram nos Grupos IV, V e VI a partir de 16 semanas.

Inicialmente as alterações exofíticas eram papiliformes, de superfície branca com áreas avermelhadas e, em geral, pediculadas. Quando as lesões atingiam de 0,4 a 1,5 $\mathrm{cm}$, em seu maior eixo, apresentavam a cor predominantemente avermelhada e a superfície lobulada, semelhante à framboesa (Figuras 3 e 5). Nestas lesões, observavamse extensas áreas de necrose superficial, com destacamento de fragmentos de lesão, acompanhado de recobrimento da área por pseudomenbrana esbranquiçada.

De uma maneira geral, as lesões iniciavam-se entre a borda lateral e o assoalho bucal. Com o crescimento tumoral, a língua era deslocada para o lado oposto (Figuras 3 e 4) e o aspecto debilitado do animal era evidente durante o seu manuseio. Após a fixação, 
as peças cirúrgicas confirmaram a morfologia e a localização das lesões (Figuras 3C, 6A e 6B).

Durante a necropsia, os órgãos e linfonodos removidos não apresentaram alterações morfológicas compatíveis com neoplasias em todos os grupos experimentais.

No decorrer do período experimental de 20 semanas, dez animais morreram principalmente por ação canibalesca típica destes animais, sendo 3 animais do grupo II, 1 animal dos grupos III, V e VI e 4 animais do grupo VII. 


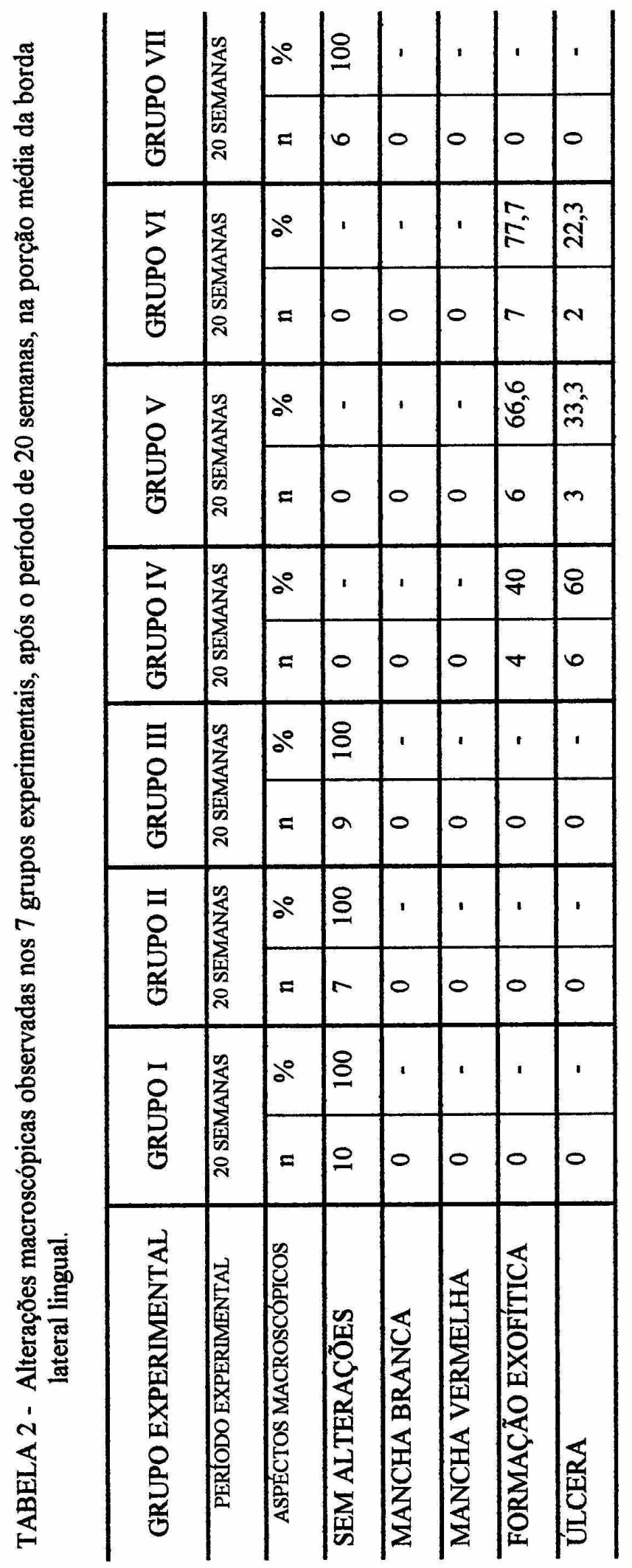




\section{2 - ANÁLISE MICROSCÓPICA}

Os dados referentes às alterações microscópicas encontradas, bem como os valores numéricos atribuídos, e, as respectivas medianas, estão registrados nas Tabelas 3a, 3b e 3c para todos os grupos experimentais no período de 20 semanas.

Os animais dos grupos controle I (acetona) e VII (água destilada) mantiveram a normalidade durante todo o experimento. Nos grupos II (Opalescence) e III (White \& Brite), os animais não desenvolveram alterações displásicas.

Nos grupos IV, V e VI as alterações neoplásicas foram muito severas com formações exofíticas e papilomatosas (Figuras 3 e 4). No grupo IV (DMBA), de 10 animais, 1 apresentou hiperplasia e hiperqueratose com displasia leve, 3 animais desenvolveram hiperplasia e hiperqueratose com displasia intensa e 3 apresentaram carcinomas epidermóides microinvasivos e 3 carcinomas epidermóides invasivos sem metástase.

No grupo V (Opalescence + DMBA), de 9 animais, 2 desenvolveram carcinomas epidermóides microinvasivos e 7 carcinomas epidermóides invasivos sem metástase. O grau histológico do carcinoma epidermóide variou de pouco a bem diferenciado ${ }^{77,78}$. No grupo VI (White \& Brite), de 9 animais, 1 apresentou hiperplasia e hiperqueratose com displasia intensa e 8 carcinomas epidermóides invasivos sem metástase. Os resultados estão descritos na Tabela 4 e representados esquematicamente na Figura 1.

A análise histológica revelou carcinomas epidermóides com infiltração para os tecidos adjacentes invadindo o tecido muscular da língua, sendo essa invasão característica de malignidade, bem como a presença em abundância de mitoses múltiplas, 
atípicas, pleomorfismo, disqueratose, pérolas córneas, hipercromatismo do núcleo, hiperplasia e hiperqueratose. Carcinomas com severo grau de invasão foram desenvolvidos nos grupos V e VI (Figuras 3 e 4).

Encontram-se ilustradas fotograficamente nas Figuras 4, 7 e 8 as alterações celulares e teciduais correspondentes a : à perda da polaridade das células basais; à presença de mais de uma camada de células com aspecto basalóide; ao aumento do índice núcleo/citoplasmático; ao aumento do número de figuras de mitose; ao pleomorfismo celular e ao hipercromatismo nuclear.

Na comparação entre os grupos utilizou-se a análise de variância de Kruskal Wallis (Tabela 5), mostrando diferenças estatisticamente significantes entre os 7 grupos experimentais $(\mathrm{p}<0.01)$. De acordo com os testes estatísticos de Mann Whittney não houve diferenças estatisticamente significantes entre os grupos V e VI (Tabela 6), porém quando comparados ao grupo IV apresentaram diferenças significantes do ponto de vista estatístico $(\mathrm{p}<0,05)$. O grupo IV foi comparado com os grupos II, III, V e VI conforme Tabelas 7, 8, 9 e 10 respectivamente.

Neste trabalho, as observações microscópicas dos órgãos internos, tais como: rins, fígado, pulmões e linfonodos, revelaram alterações como degeneração hidrópica, associadas ou não à eosinofilia aumentada, ainda que discreta. Nos resultados não foram considerados estes fenômenos por tratarem-se de alterações associadas ao sacrifício dos animais por anoxia. 


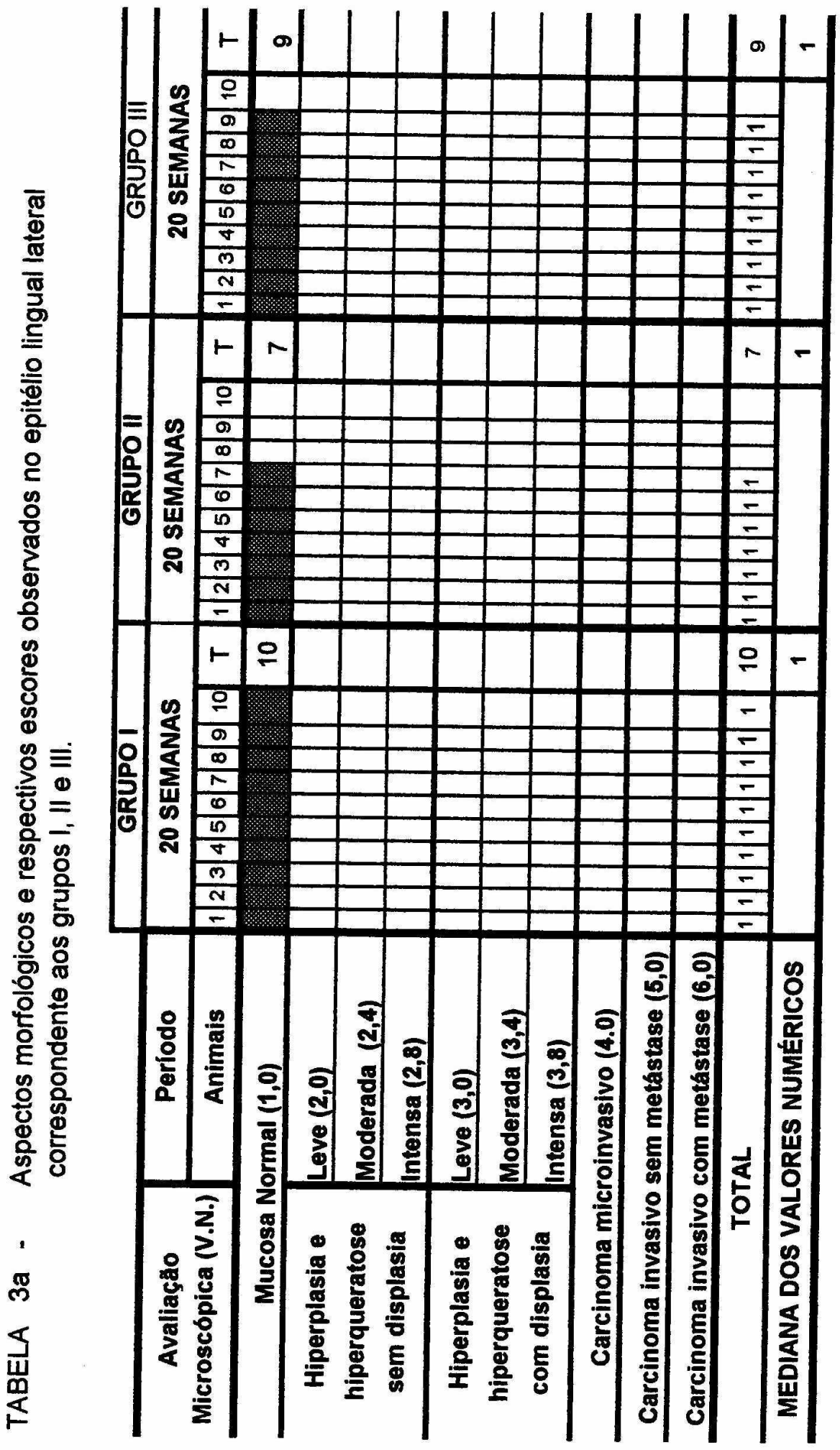




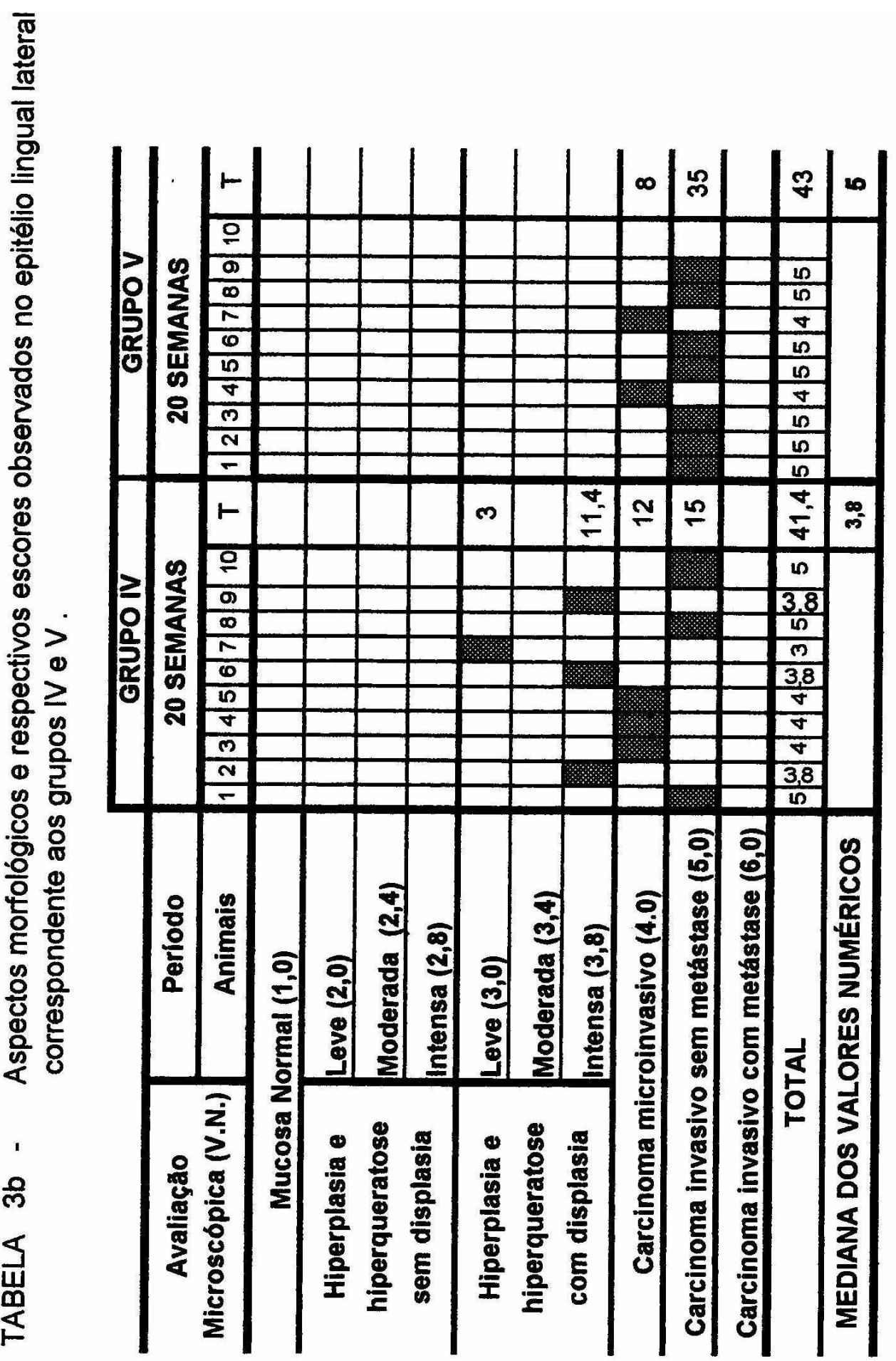




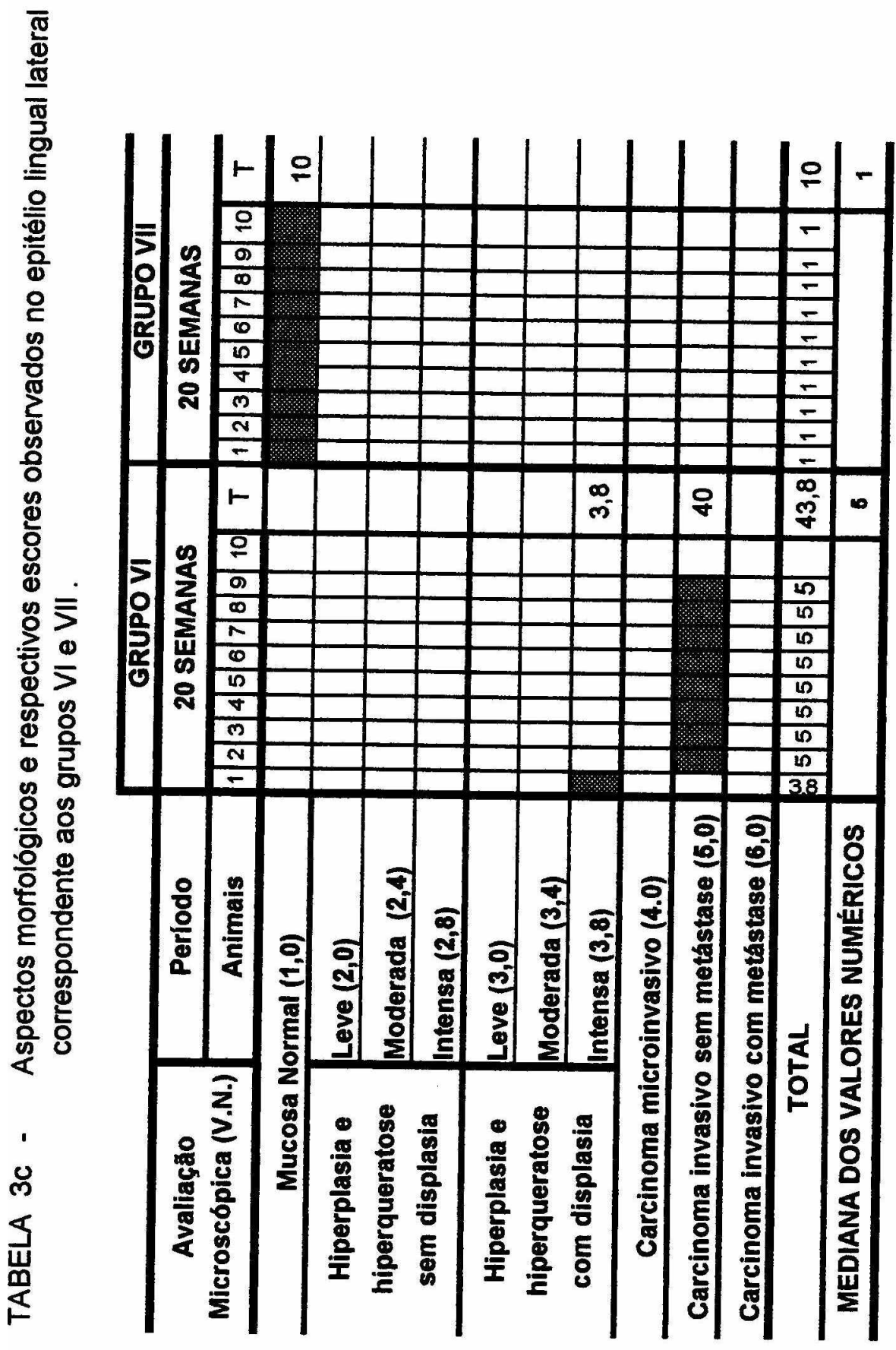


TABELA 4 - Distribuição dos aspectos morfológicos decorrentes da carcinogênese induzida, no período de 20 semanas

\begin{tabular}{cccccc}
\hline Grupos & $\begin{array}{c}\text { Número de } \\
\text { animais }\end{array}$ & $\begin{array}{c}\text { Hiperplasia } \\
\text { intensa }\end{array}$ & $\begin{array}{c}\text { Displasi } \\
\text { a }\end{array}$ & $\begin{array}{c}\text { Carcinoma } \\
\text { invasivo }\end{array}$ & $\begin{array}{c}\text { Carcinoma } \\
\text { micro-invasivo }\end{array}$ \\
\hline I & 10 & - & - & - & - \\
II & 7 & - & - & - & - \\
III & 9 & - & - & - & - \\
IV $^{\Delta}$ & 10 & - & 4 & 3 & 3 \\
V $^{*}$ & 9 & - & - & 7 & 2 \\
VI $^{*}$ & 9 & 1 & - & 8 & - \\
VII & 6 & - & - & - & - \\
\hline
\end{tabular}

Diferenças significantes entre os grupos ( $\mathrm{p}<0,01)$ (variações de Kruskal Wallis).

* Não houve diferença estatística entre estes grupos ( teste de Mann Whitney).

${ }^{\Delta}$ Diferenças significantes entre os grupos V e VI $(\mathrm{p}<0,05)$ (teste de Mann Whitney)

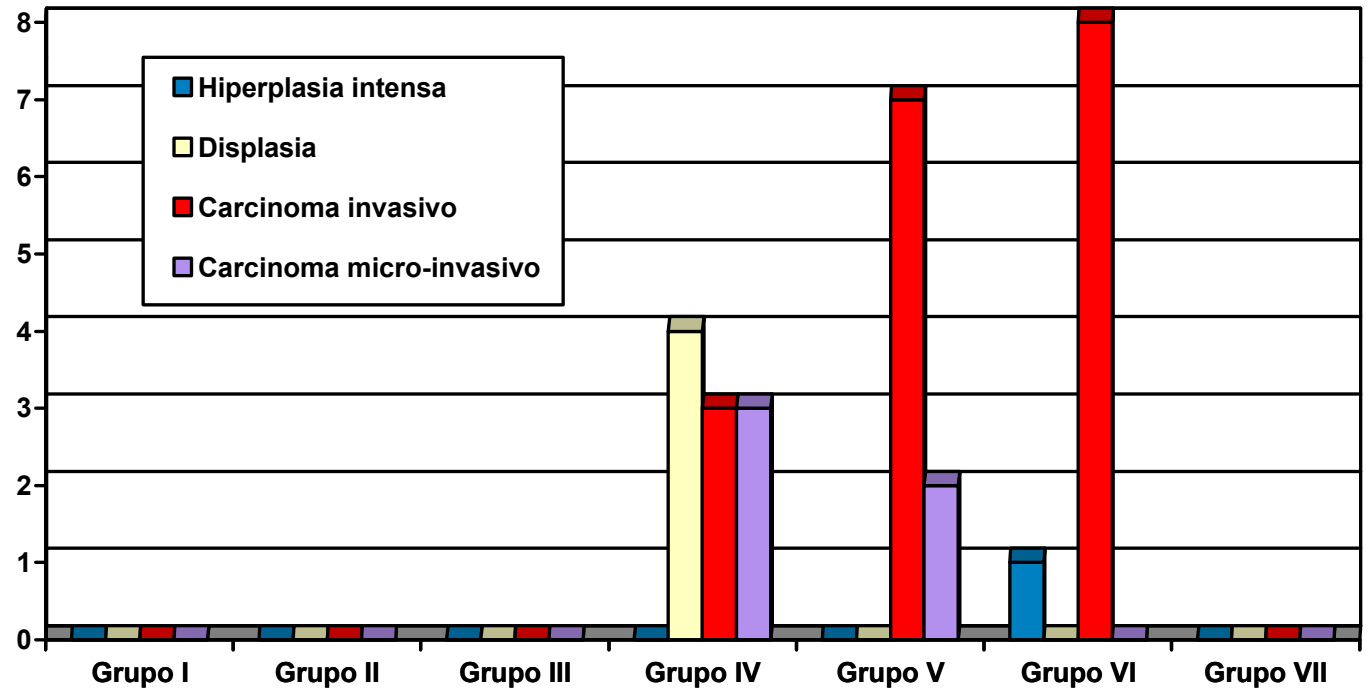

FIGURA 1 - Distribuição gráfica dos aspectos morfológicos decorrentes da carcinogênese induzida, no período de 20 semanas 
TABELA 5 - Análise de variância de Kruskal-Wallis para comparação entre os 7 grupos experimentais no período de 20 semanas

\begin{tabular}{c|c|c}
\hline Tempo(semanas) & gl & $\mathrm{H}$ \\
\hline 20 & 6 & $47,70^{*}$ \\
\hline
\end{tabular}

* significante $(\mathrm{p}<0,01)$

$\mathrm{gl}=$ grau de liberdade

TABELA 6- Teste de Mann Whitney para comparação entre os grupos V e VI no período de 20 semanas

\begin{tabular}{c|c|c|c|c|c|c|c}
\hline Período & \multicolumn{2}{|c|}{ GrupoV } & \multicolumn{2}{c|}{ GrupoVI } & & \multicolumn{2}{c}{ U crit. (bilateral) } \\
\hline semanas & $\mathrm{N} 1$ & $\mathrm{R} 1$ & $\mathrm{~N} 2$ & $\mathrm{R} 2$ & $\mathrm{U}$ & $\mathrm{p}<0,05$ & $\mathrm{P}<0.01$ \\
\hline 20 & 9 & 51,94 & 9 & 52,72 & 37 & 17 & 14 \\
\hline
\end{tabular}

$*$ = estatisticamente significante

$\mathrm{N}$ = número de elementos

$\mathrm{R} 1$ = soma dos postos atribuídos ao grupo cujo tamanho da amostra é N1.

$\mathrm{R} 2$ = soma dos postos atribuídos ao grupo cujo o tamanho da amostra é N2. 
TABELA 7 - Teste de Mann Whitney para comparação entre os grupos II e IV no período de 20 semanas

\begin{tabular}{c|c|c|c|c|c|c|c}
\hline Período & \multicolumn{2}{|c|}{ Grupo II } & \multicolumn{2}{c|}{ GrupoIV } & & \multicolumn{2}{c}{ U crit. (bilateral) } \\
\hline semanas & N1 & R1 & N2 & R2 & U & $\mathrm{p}<0,05$ & $\mathrm{p}<0,01$ \\
\hline 20 & 7 & 18 & 10 & 44,4 & 0 & 14 & 11 \\
\hline
\end{tabular}

$\mathrm{N}=$ Número de elementos

$\mathrm{R} 1$ = soma dos postos atribuídos ao grupo cujo tamanho da amostra é N1.

$\mathrm{R} 2$ = soma dos postos atribuídos ao grupo cujo tamanho da amostra é N2.

TABELA 8 - Teste de Mann Whitney para comparação entre os grupos III e IV no período de 20 semanas

\begin{tabular}{c|c|c|c|c|c|c|c}
\hline Período & \multicolumn{2}{|c|}{ Grupo II } & \multicolumn{2}{c|}{ GrupoIV } & & \multicolumn{2}{c}{ U crit. (bilateral) } \\
\hline semanas & N1 & R1 & N2 & R2 & U & $\mathrm{p}<0,05$ & $\mathrm{p}<0,01$ \\
\hline 20 & 7 & 18 & 10 & 44,4 & 0 & 14 & 11 \\
\hline
\end{tabular}

$\mathrm{N}=$ número de elementos

$\mathrm{R} 1$ = soma dos postos atribuídos ao grupo cujo tamanho da amostra é N1.

$\mathrm{R} 2$ = soma dos postos atribuídos ao grupo cujo o tamanho da amostra é N2. 
TABELA 9 - Teste de Mann Whitney para comparação entre os grupos V e IV no período de 20 semanas

\begin{tabular}{c|c|c|c|c|c|c|c}
\hline Período & \multicolumn{2}{|c|}{ GrupoV } & \multicolumn{2}{c|}{ Grupo IV } & & \multicolumn{2}{c}{ U crit.(bilateral) } \\
\hline semanas & $\mathrm{N} 1$ & $\mathrm{R} 1$ & $\mathrm{~N} 2$ & $\mathrm{R} 2$ & $\mathrm{U}$ & $\mathrm{p}<0,05$ & $\mathrm{p}<0.01$ \\
\hline 20 & 9 & 51,94 & 10 & 44,4 & 19,5 & $20^{*}$ & 16 \\
\hline
\end{tabular}

* estatisticamente significante

$\mathrm{N}=$ número de elementos

$\mathrm{R} 1$ = soma dos postos atribuídos ao grupo cujo tamanho da amostra é N1.

$\mathrm{R} 2$ = soma dos postos atribuídos ao grupo cujo o tamanho da amostra é N2.

TABELA 10 - Teste de Mann Whitney para comparação entre os grupos VI e IV no período de 20 semanas

\begin{tabular}{c|c|c|c|c|c|c|c}
\hline Período & \multicolumn{2}{|c|}{ GrupoVI } & \multicolumn{2}{c|}{ Grupo IV } & & \multicolumn{2}{c}{ U crit.(bilateral) } \\
\hline semanas & $\mathrm{N} 1$ & $\mathrm{R} 1$ & $\mathrm{~N} 2$ & $\mathrm{R} 2$ & $\mathrm{U}$ & $\mathrm{p}<0,05$ & $\mathrm{p}<0,01$ \\
\hline 20 & 9 & 52,72 & 10 & 44,4 & 0 & $20^{*}$ & 16 \\
\hline
\end{tabular}

* estatisticamente significante

$\mathrm{N}$ = número de elementos

R1 = soma dos postos atribuídos ao grupo cujo tamanho da amostra é N1.

$\mathrm{R} 2$ = soma dos postos atribuídos ao grupo cujo o tamanho da amostra é N2. 

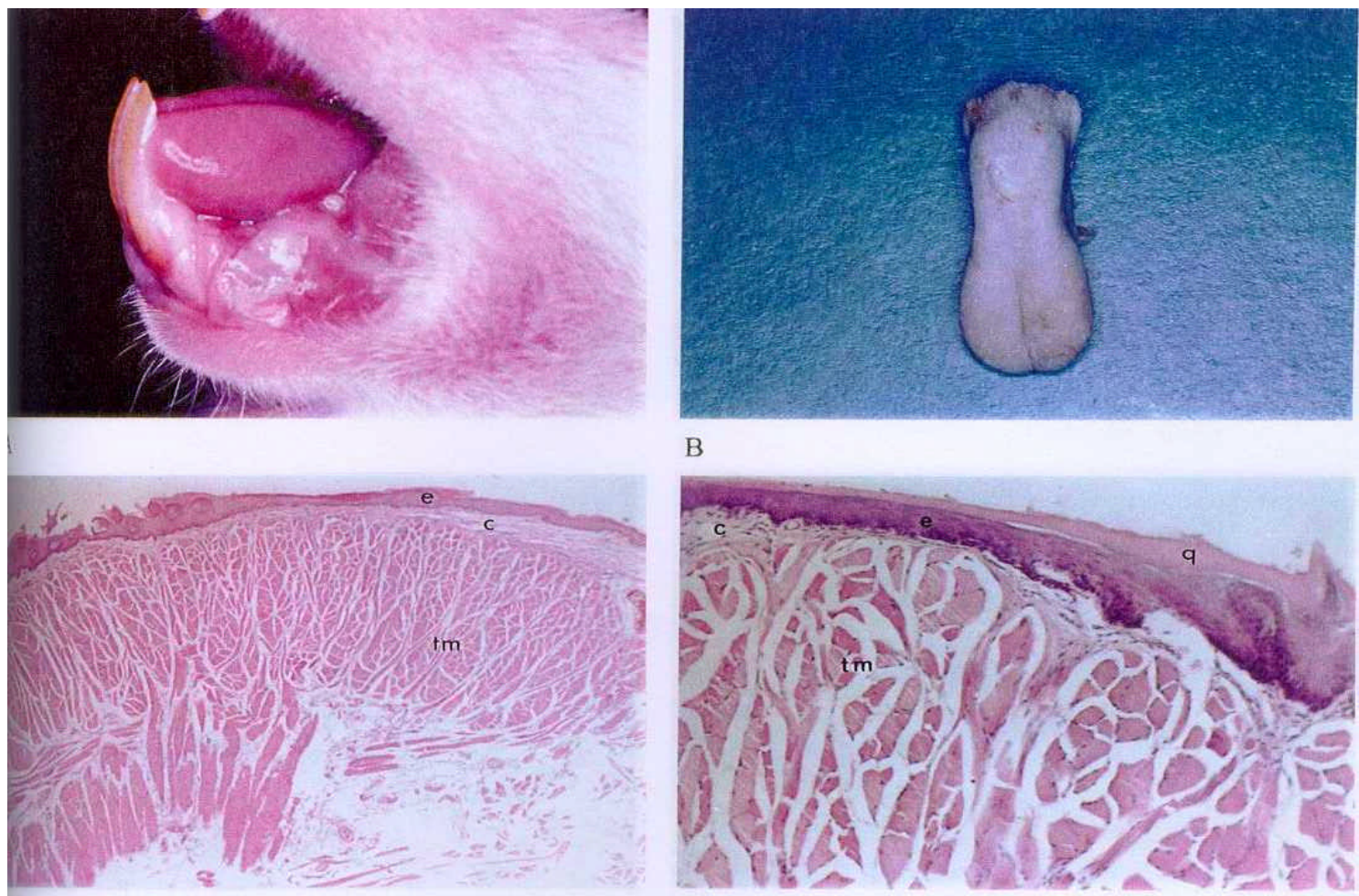

B

$\mathrm{C}$

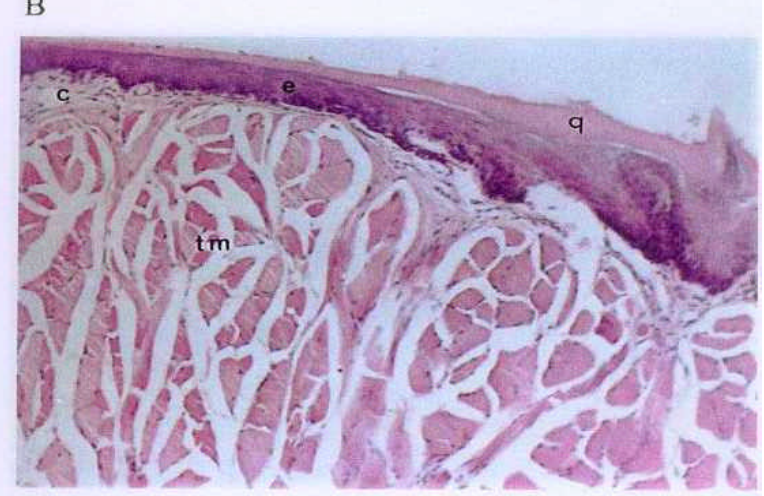

$\mathrm{D}$

Figura 2 - A e B: Aspecto macroscópico normal da mucosa da borda lateral lingual de hamster sírio dourado; C e D: aspectos microscópicos normais da mucosa e submucosa lingual. Observar o epitélio constituído por poucas camadas celulares (e), tecido conjuntivo sub-epitelial pouco espesso(c), tecido muscular proeminente (tm) e presença de queratina (q).

(Aumento original: $\mathbf{C}=10 x, \mathbf{D}=40 \mathrm{x}$ ). H. E. 

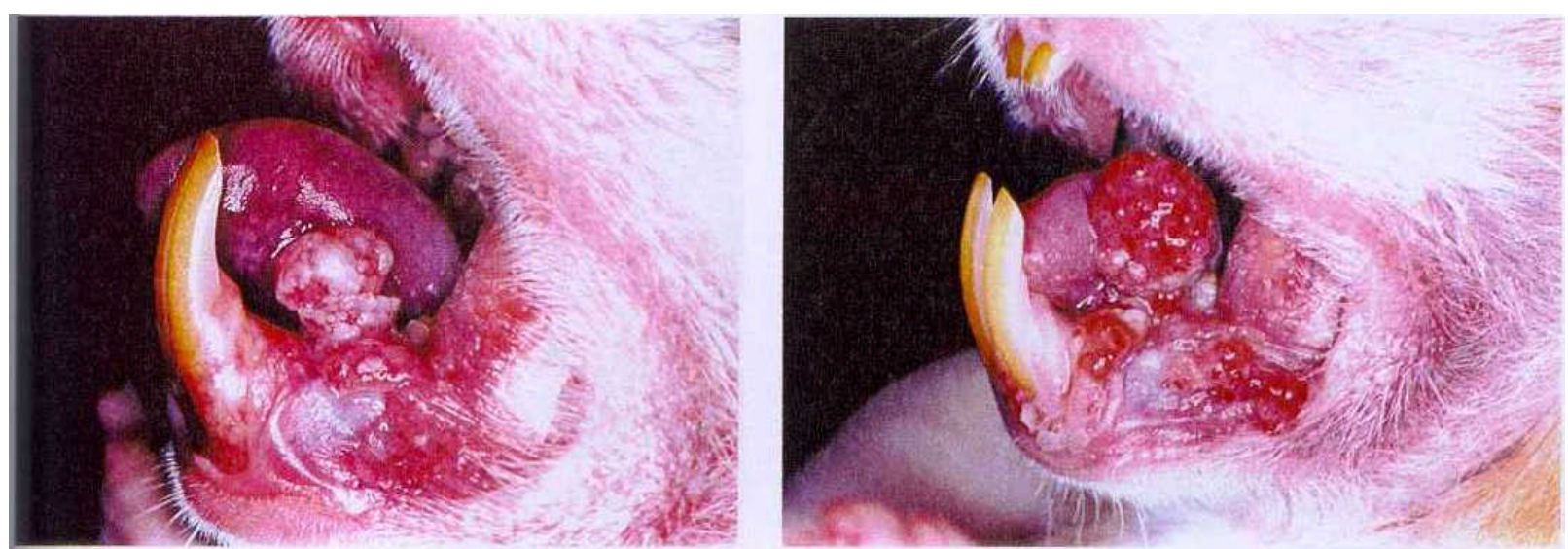

B
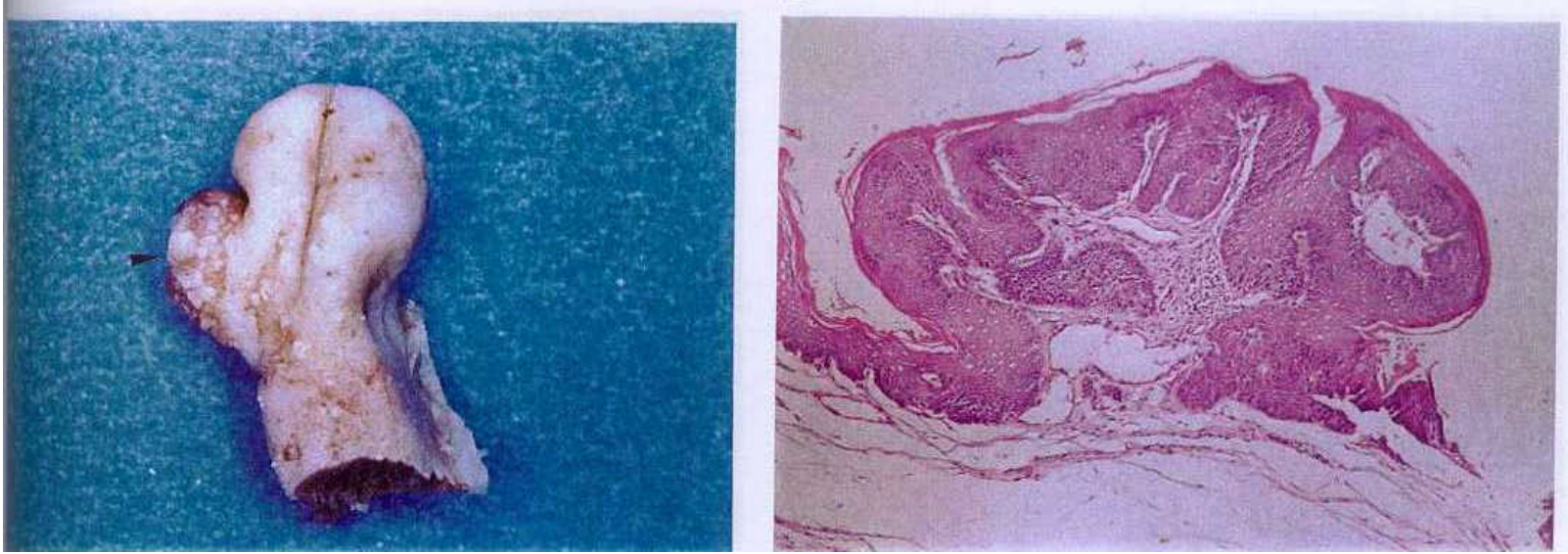

$\mathrm{C}$

$\mathrm{D}$

FIGURA 3 - Grupo IV (DMBA) A e B: Formação exofítica avermelhada na porção média da borda lateral lingual, do carcinoma epidermóide DMBA-induzido após período de 20 semanas; C: aspecto macroscópico da lesão lingual observada na figura anterior (seta); D: aspecto microscópico do carcinoma epidermóide na porção média lingual destacando o crescimento epitelial exofítico. (Aumento original: $\mathrm{D}=100 \mathrm{x}$ ). H. E. 

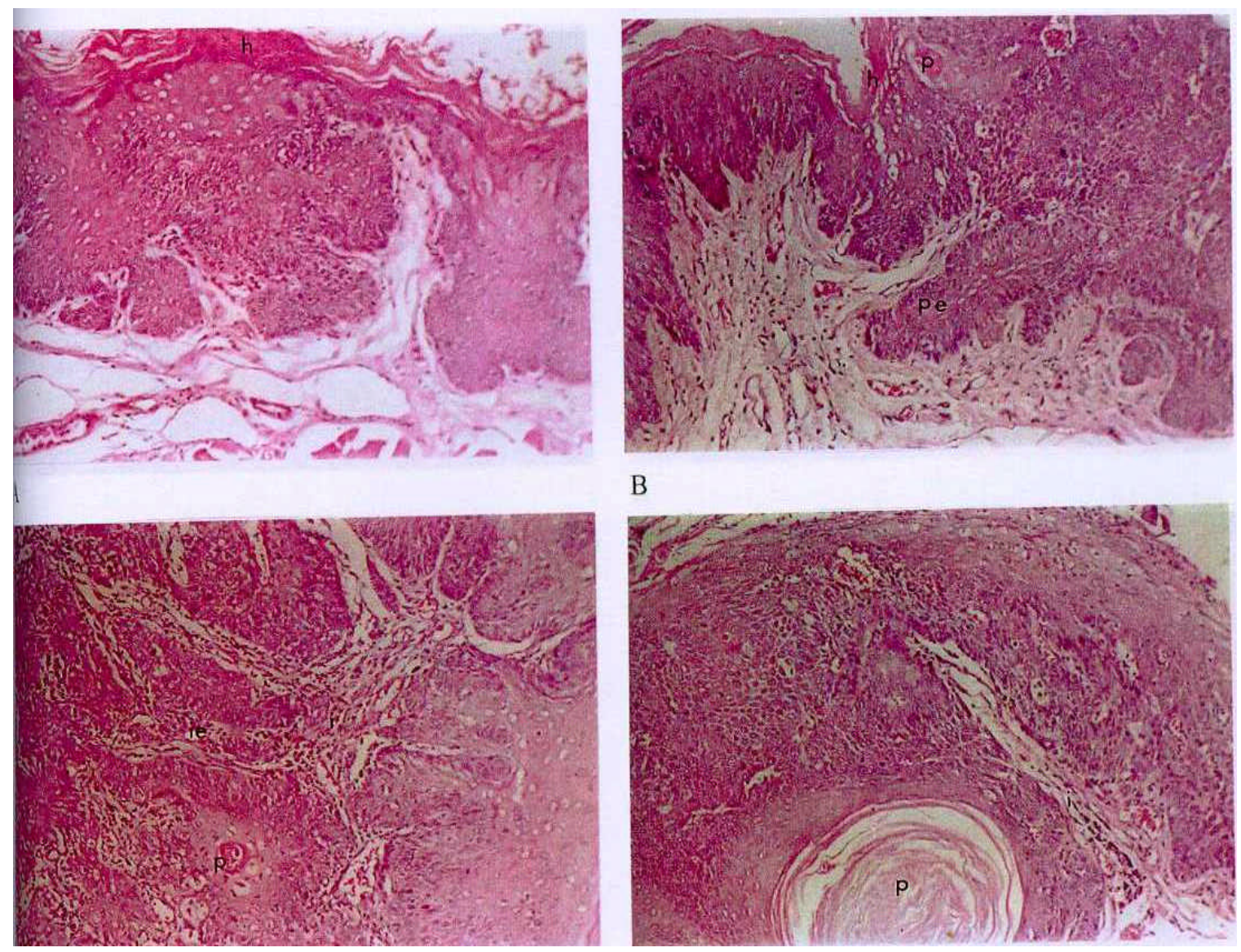

$\mathrm{C}$

$\mathrm{D}$

FIGURA 4 - Grupo IV (DMBA) Aspectos microscópicos de carcinoma epidermóide DMBA-induzido bem diferenciado na borda lateral lingual, após período de 20 semanas; A e B: carcinoma microinvasivo com áreas de hiperqueratinização superficial (h) além de: mitoses atípicas, pelomorfismo, hipercromatismo e pérolas córneas. Notar projeção do epitélio (pe); C e D: presença de ilhotas epiteliais (ie) permeadas por infiltrado inflamatório (i) e áreas com pérolas córneas (p). (Aumento original: A, B, C e D = 40x). H. E. 

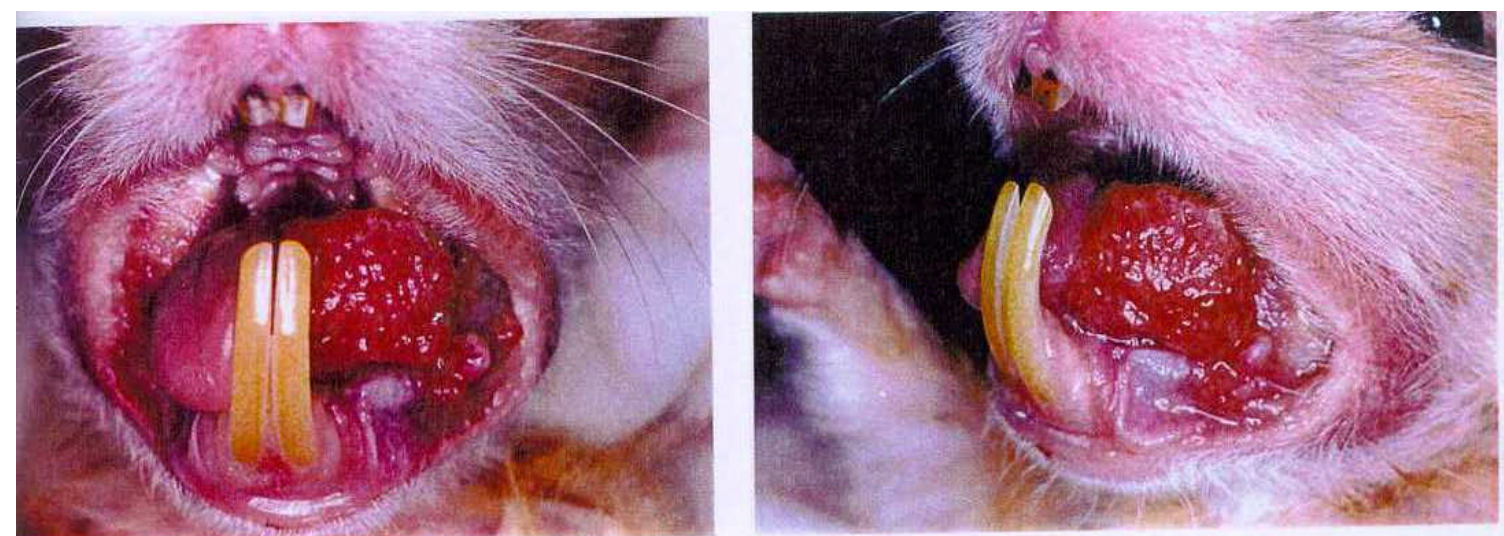

B
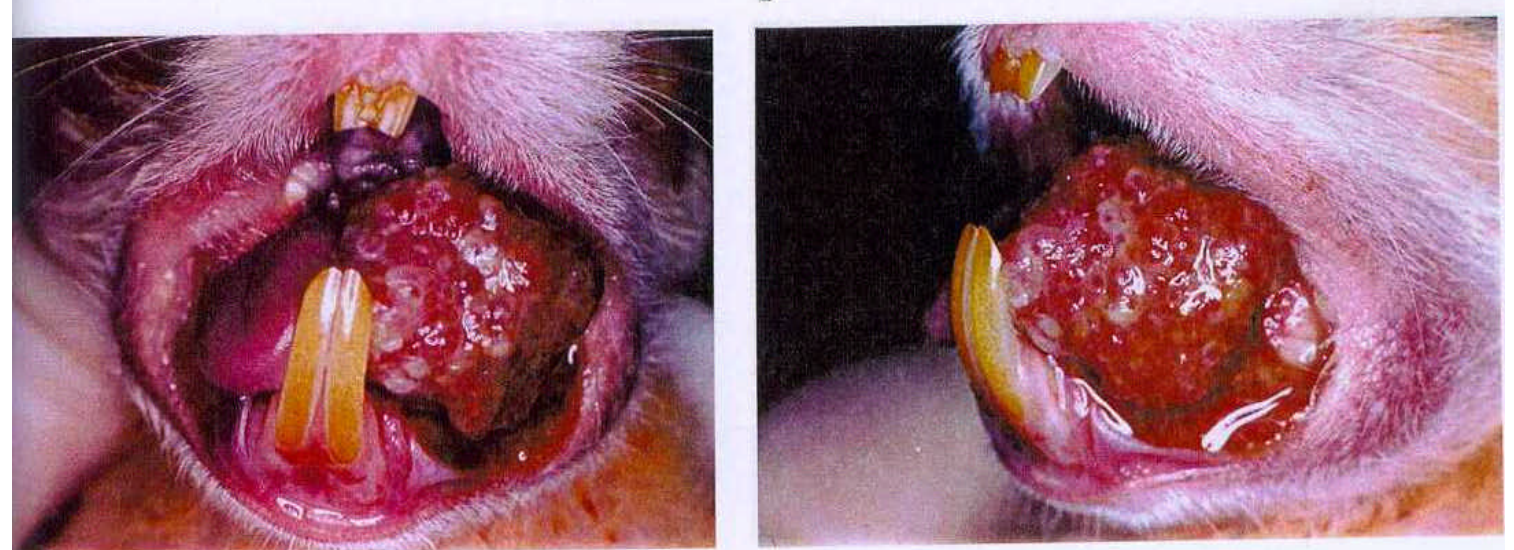

$\mathrm{C}$

$\mathrm{D}$

FIGURA 5 - Grupos V e VI (peróxido de carbamida a 10\% + DMBA) em A, B, C e D formações exofíticas na mucosa lingual de hamster sírio dourado em estágio avançado de carcinoma epidermóide, sangrantes ao toque, após período de 20 semanas. 

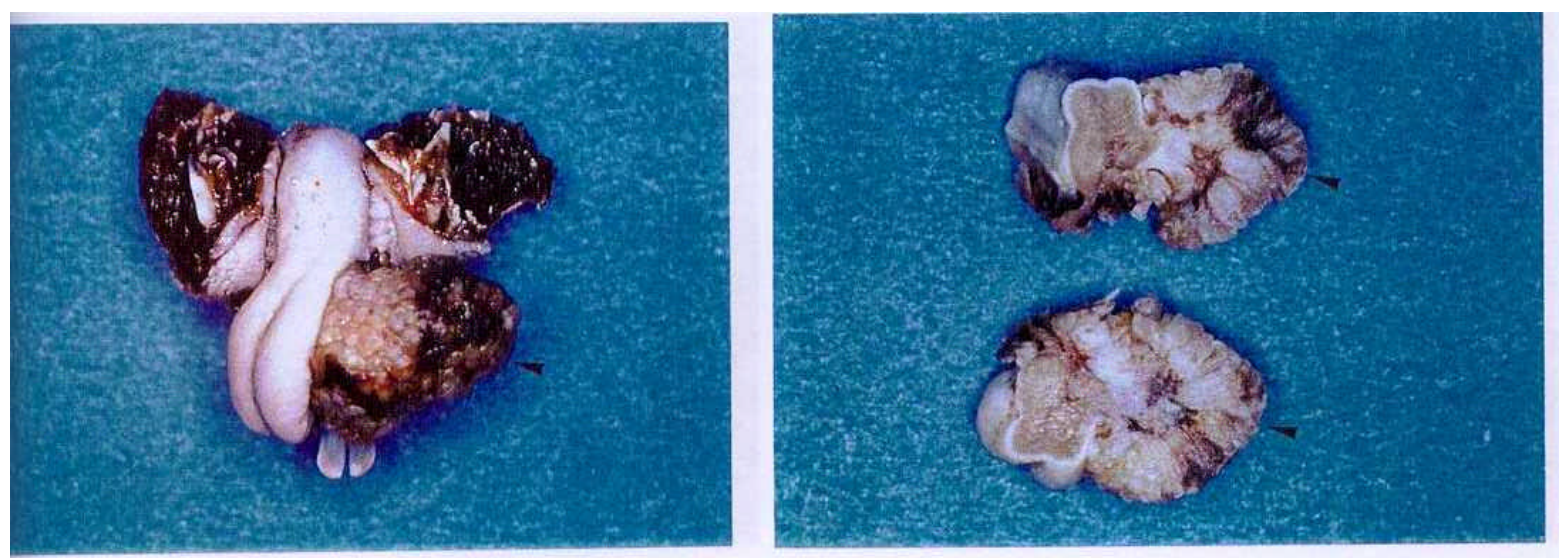

B
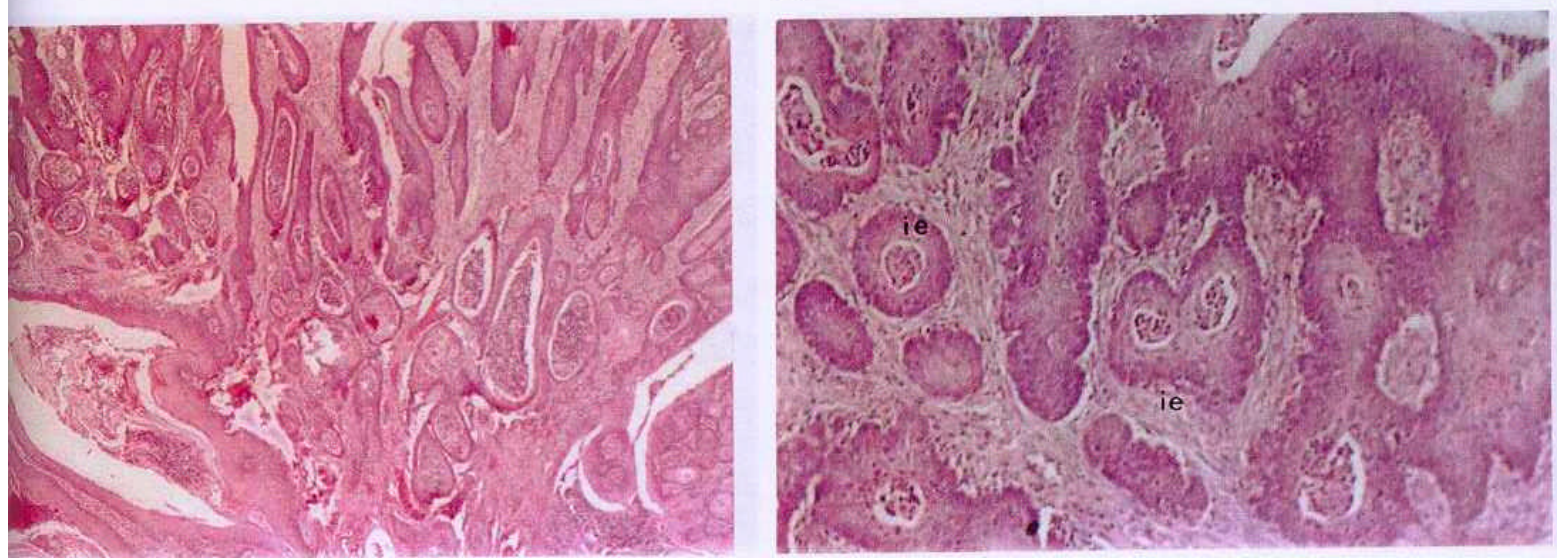

$\mathrm{C}$

$\mathrm{D}$

FIGURA 6 - A: Macroscopia da lesão lingual do carcinoma epidermóide DMBA-induzido (seta) nos grupos que receberam peróxido de carbamida a 10\% + DMBA; B: corte transversal da lesão descrita em A (seta); C: aspecto microscópico do crescimento exofítico do carcinoma com múltiplas papilas; D: observar ilhotas epiteliais (ie) características da invasividade do carcinoma. (Aumento original: $\mathrm{C}=40 \mathrm{x}, \mathrm{D}=10 \mathrm{x}$ ). H. $\mathrm{E}$. 

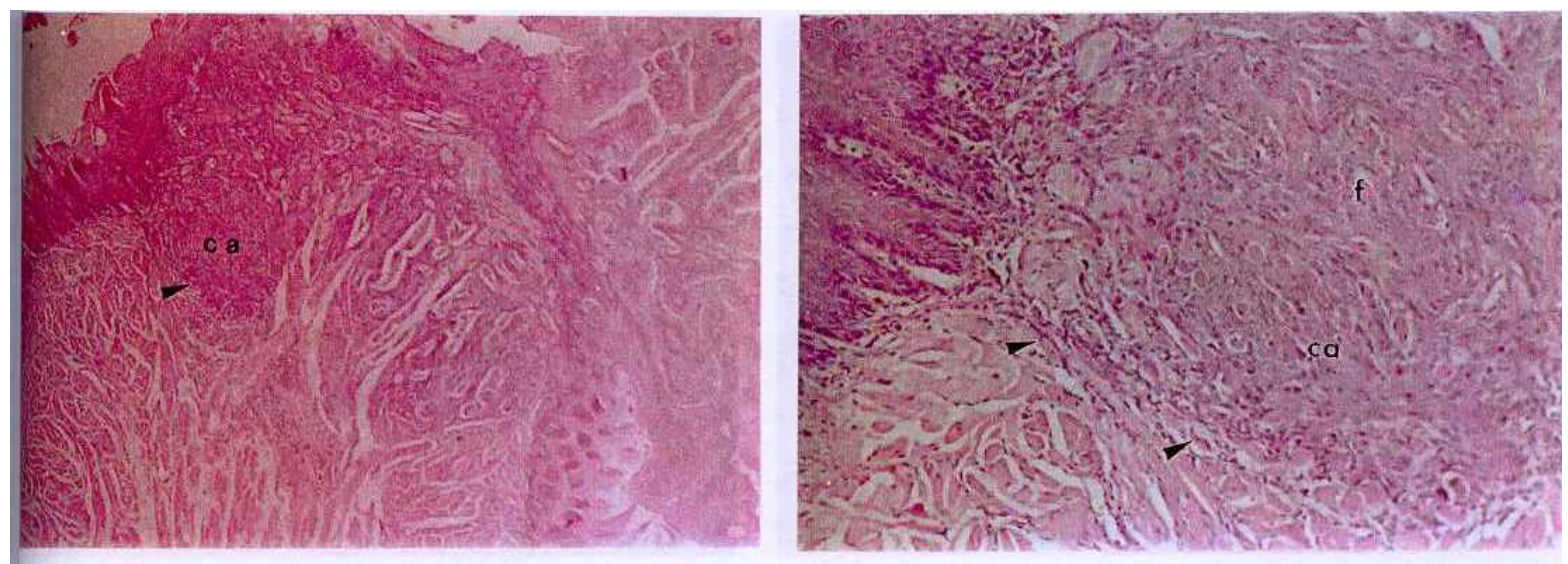

B
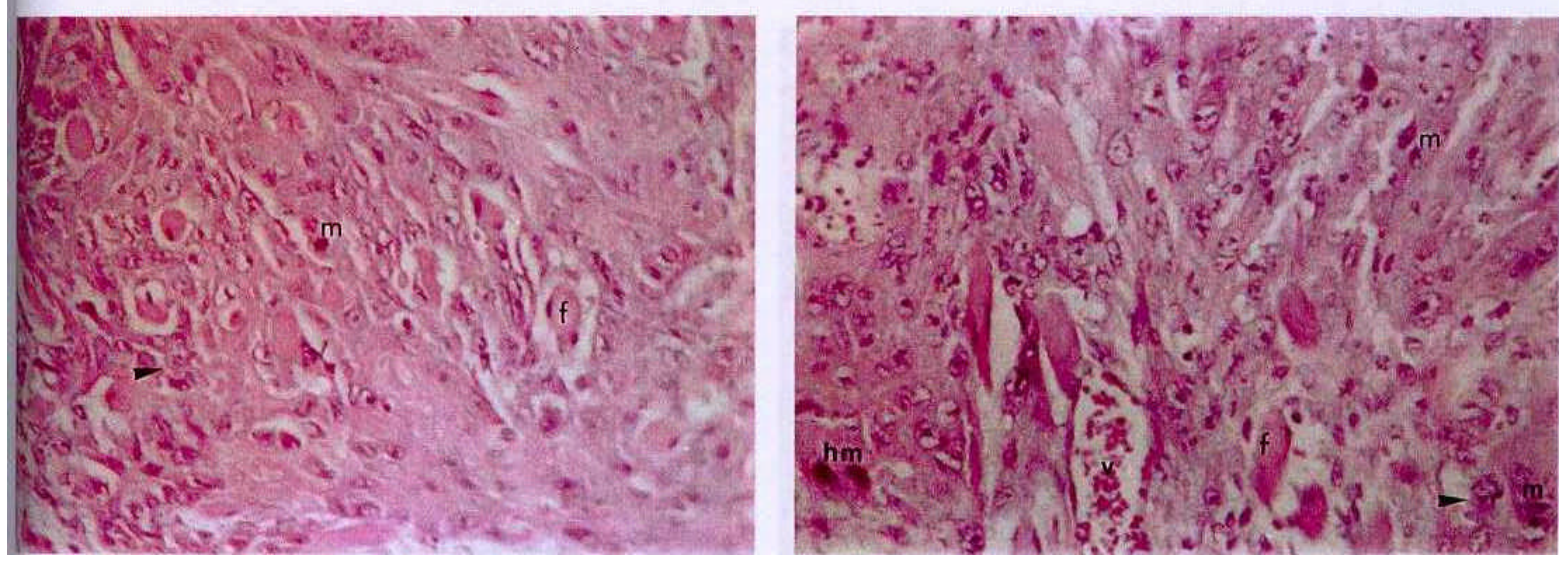

FIGURA 7 - Grupo V (Peróxido de carbamida a 10\% + DMBA) A: Aspecto microscópico de carcinoma epidermóide bem diferenciado na borda lateral lingual após 20 semanas evidenciando a desorganização epitelial com invasão da submucosa; B: observa-se comprometimento acentuado da camada muscular e o limite do tecido muscular normal (seta); C e D: detalhe do quadro microscópico descrito em A e B destacando a invasão e destruição das fibras musculares esqueléticas. $\mathrm{m}=$ mitoses atípicas, $\mathrm{hm}=$ hipercromatismo, $\mathrm{f}=$ fibras musculares, $\mathrm{Ca}=$ carcinoma, pleomorfismo celular $($ seta), $\mathrm{v}=$ vasos sanguíneos congestos . (Aumento original: $\mathrm{A}=10 \mathrm{x}, \mathrm{B}=40 \mathrm{x}, \mathrm{C}$ e $\mathrm{D}=100 \mathrm{x}$ ). H. $\mathrm{E}$. 

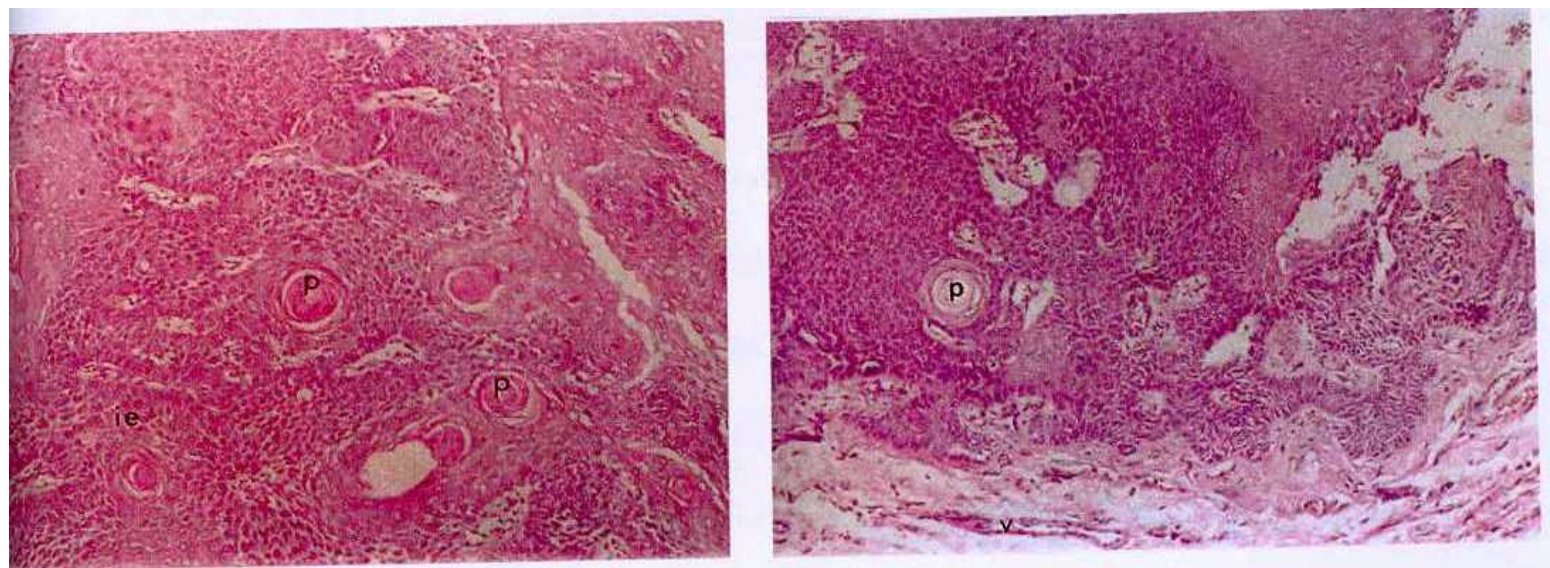

$\mathrm{B}$
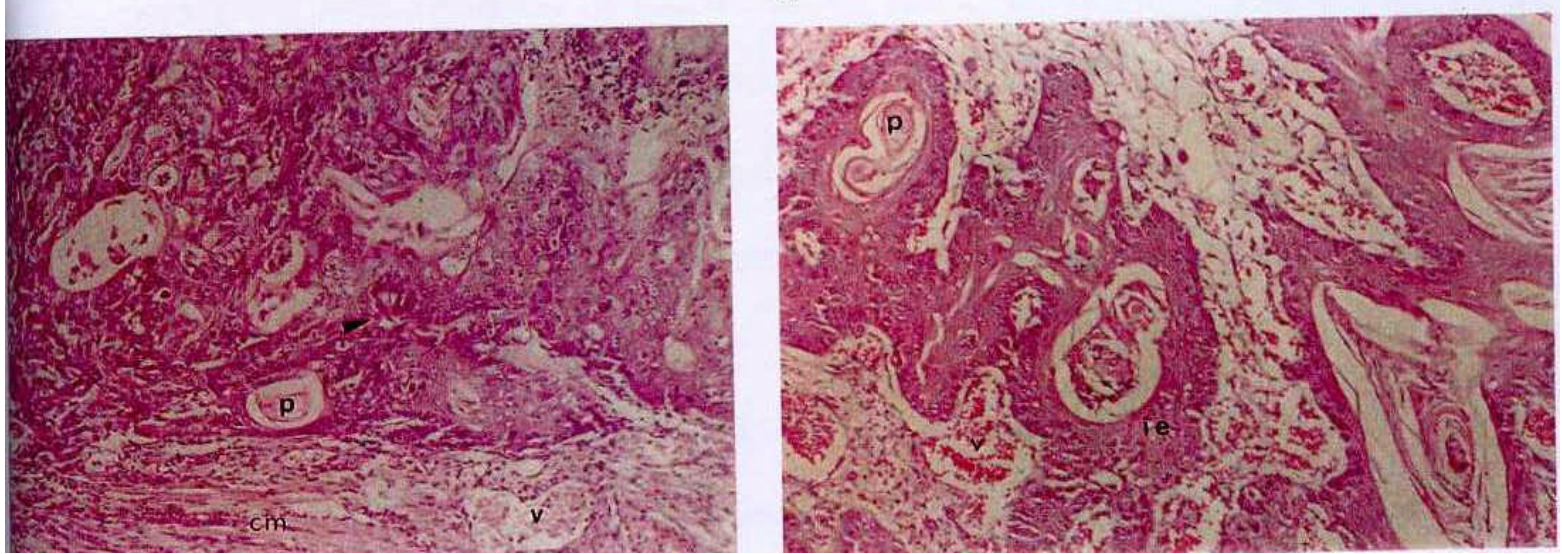

$\mathrm{C}$

$\mathrm{D}$

FIGURA 8 - Grupo VI (peróxido de carbamida a 10\% + DMBA) A e B: Aspectos microscópicos do carcinoma epidermóide bem diferenciado após 20 semanas com formação de pérolas córneas e aspecto de invasão tecidual demonstrado por ilhotas epiteliais permeadas por tecido conjuntivo, intensas mitoses atípicas, hipercromatismo, pleomorfismo; C e D: notar a invasão tecidual das ilhotas de epitélio comprometendo a camada muscular da língua (seta). $\mathrm{p}=$ pérolas córneas, $\mathrm{cm}=$ camada muscular, $\mathrm{v}=$ vasos sanguíneos congestos, $\mathrm{Ca}=$ carcinoma, ie = ilhotas epiteliais. (Aumento original: A, B, C e D = 40x). H. E. 


\section{6 - DISCUSSÃO}




\section{6 - DISCUSSÃO}

O desenvolvimento do câncer compreende uma interação de vários fatores como o genético ou hereditário e os fatores externos relacionados com o meio ambiente, originando o chamado câncer ambiental ${ }^{7,42,65,68}$. É um processo que se prolonga, geralmente, por meses ou anos, constituindo um somatório de efeitos de agentes carcinogênicos $^{92}$. A grande prevalência de câncer bucal se relaciona com a ação de agentes e de fatores físicos e químicos. No mundo moderno, com a industrialização, as substâncias químicas possuem grande importância na indução de cânceres em humanos $^{64,82,83}$. Aproximadamente $80 \%$ de todos os cânceres associam-se aos componentes do meio ambiente ${ }^{42,75}$. As substâncias químicas, potencialmente carcinogênicas, parecem ser a causa mais importante e conhecida de câncer, pois as freqüentes exposições a elas, em consequiência dos hábitos alimentares, hábitos sociais (como bebidas alcoólicas e cigarro) e poluentes ambientais passaram a exercer, ao longo do tempo, influência sobre o desenvolvimento dessa doença ${ }^{42,64}$.

Muitas destas substâncias já foram analisadas e ao longo dos anos algumas foram retiradas do mercado, porém inúmeras outras estão sendo utilizadas sem que se saiba de forma conclusiva qual a sua potencialidade em causar mutações celulares. Aproximadamente 60 produtos, dentre eles: o álcool, o cigarro, os aditivos alimentares (aromatizantes e corantes), os gases industriais, os metais (cádmio, selênio, berílio, mercúrio, níquel, zinco, cobalto), os pesticidas, os agrotóxicos e as radiações solares já foram catalogados como agentes indutores, promotores de carcinogênese ou como produtos químicos co-carcinogênicos representados por aqueles produtos que 
isoladamente não causam câncer, mas na presença de outras substâncias (iniciadoras ou promotoras) podem desenvolver tumores ${ }^{3}$. Muitos dos produtos citados são utilizados em escala industrial ou na agricultura e, inadvertidamente, na maioria das vezes sem o adequado controle $\mathrm{e}^{3,7,42,56,63,65,71,83}$

O cigarro e o álcool são exemplos de substâncias químicas que provocam transformações celulares ${ }^{38}$. Estudos epidemiológicos evidenciam que as bebidas alcoólicas podem induzir câncer em humanos ${ }^{10}$. Quando se faz a associação do álcool e cigarro, a incidência do desenvolvimento de câncer bucal aumenta significativamente: o álcool e o fumo são fatores etiológicos importantes no desenvolvimento de carcinomas no lábio e na cavidade bucal $^{10,11,50}$. Um efeito sinérgico desses vícios é demonstrado por vários $_{\text {autores }}^{10,11}$. O fumo teria efeito iniciador e o álcool um promotor de neoplasias $^{10,11,24,28,50,52}$.

Por outro lado, pesquisas discutem a possibilidade dos componentes alimentares conferirem proteção às células no processo de desenvolvimento de alguns tipos de canceres, com uma ação antioxidativa, tais como: a vitamina A, a pró-vitamina A (caroteno, betacarotenóides), vitamina C, vitamina E, B2 e as fibras ou por alteração de enzimas que envolvem o metabolismo de carcinógenos. Sabe-se que a dieta da maioria da população brasileira é inadequada tanto pela qualidade quanto pela quantidade, estando em níveis bem inferiores àqueles que, supostamente, seriam necessários para ocorrer alguma prevenção. Os estudos epidemiológicos e experimentais sugerem que os alimentos apresentam um importante papel modulador no desenvolvimento de alguns tipos de câncer, porém, até o momento, não foi encontrada uma dieta ideal ${ }^{56,63,66}$.

O aparecimento do câncer não está na dependência de um ou outro fator de risco isolado, mas é fruto da interação de vários fatores de risco em maior ou menor grau e que 
podem danificar o equilíbrio celular causando alterações irreversíveis no DNA das células desenvolvendo então as neoplasias ${ }^{63}$.

A carcinogênese química caracteriza-se por um processo de múltiplas etapas $^{8,42,53,69,70,78}$. O primeiro estágio é a iniciação que ocorre rapidamente e de forma irreversível. A iniciação geralmente resulta de uma ou mais mutações do DNA celular. O segundo estágio é denominado de promoção ocorrendo durante um período longo de tempo. A promoção é um processo complexo no qual as alterações celulares ocorrem a partir de células iniciadas que estimulam a proliferação celular e modulam sua diferenciação. Caracteristicamente essa fase apresenta ação reversível e depende de um limiar de dose para ser ativo, o que a diferencia da iniciação cuja ação é irreversível e independentemente da dose $\mathrm{e}^{8,53,65,70,77}$

Após a promoção o estágio seguinte é a progressão da lesão que se caracteriza microscopicamente em evolução por uma reação inflamatória, hiperplasia e finalmente a displasia celular até a evidência macroscópica da lesão onde temos então como resultado final a manifestação clínica da neoplasia ${ }^{18,32,44,56,78}$.

Com o número crescente de substâncias químicas em nosso meio surgiram estudos sobre a carcinogênese química e modelos experimentais foram criados para avaliar o potencial carcinogênico de várias substâncias, especialmente, as substâncias utilizadas nos medicamentos e nos alimentos ${ }^{8,80}$. Existem dois grupos de testes para as substâncias químicas quanto ao potencial carcinogênico: os de curta duração e longa duração ${ }^{12}$. Os testes de curta duração podem identificar as substâncias que aparentemente agem através da interação com as células, modificando a estrutura do DNA. Estes testes de curta duração por usarem sistemas relativamente simples não oferecem estimativas quantitativas de risco de várias substâncias carcinogênicas em humanos. Desta forma 
apenas os testes de mutagenicidade não são suficientes para determinar a carcinogenicidade de algumas substâncias, pois $25 \%$ a $30 \%$ destes químicos cancerígenos não tem potencial mutagênico, ou seja, de alterar o DNA, não sendo detectáveis por esses testes. No entanto, são potentes carcinógenos que atuam nas células pela proliferação celular sendo denominados de agentes não-genotóxicos. Por essa razão prefere-se utilizar a administração crônica em experimentos com animais, mais especificamente em roedores, que são os verdadeiros testes prospectivos, aos quais os agentes químicos devem ser submetidos antes de serem utilizados em qualquer atividade humana ${ }^{12}$.

Entre os testes experimentais destinados à carcinogênese química bucal, o mais tradicional baseia-se na ação de uma substância de potencial carcinogênico bem estabelecido: 9-10-Dimetil 1,2- Benzantraceno (DMBA), um hidrocarboneto aromático policíclico, cuja ação pode ser testada experimentalmente em animais de laboratório ${ }^{14} \mathrm{e}$ ainda possui ação local e propriedades comprovadas de iniciação, promoção e progressão de neoplasias, não requerendo associação com outras drogas carcinogênicas, sendo assim um carcinógeno completo ${ }^{53,69,70}$.

O DMBA produz lesões cancerizáveis e carcinomas passíveis de serem acompanhados macro e microscopicamente ${ }^{27,79}$. É encontrado sob a forma de pó e deve ser diluído para a sua utilização. Entre os diluentes citados na literatura, a acetona demonstra os melhores resultados ${ }^{31,32,60,61,80,81}$. No que concerne à concentração ficou estabelecido que a ideal é de $0,5 \%$ para o desenvolvimento tumoral ${ }^{67}$.

Os hamsters sírios dourados foram escolhidos para este experimento, pela proximidade anatômica e estrutural dos carcinomas quimicamente induzidos nesses animais, com aqueles desenvolvidos na espécie humana; e também pela possibilidade desta espécie desenvolver neoplasias malignas em um tempo menor $25,27,31,32,44,48,60,69,70,79$. 
Os carcinomas quimicamente induzidos podem ser obtidos em várias regiões da mucosa bucal. Neste trabalho, optamos pela porção média da borda lateral lingual pela facilidade de acesso e pela analogia mais direta com lesões humanas correlatas, pois sabe-se que o câncer de borda lateral lingual é o mais comum na mucosa bucal, sendo o local mais freqüentemente atingido ${ }^{25,31,32,36}$. O tempo máximo para estudo de neoplasias malignas quimicamente induzidas na literatura é de 27 semanas, sendo mais comum o período de 20 semanas, que foi o tempo escolhido para esse trabalho ${ }^{27}$.

A grande preocupação com a utilização dos agentes clareadores caseiros é o contato prolongado com os tecidos moles e seus possíveis efeitos sistêmicos. Sabe-se que, algumas reações adversas reversíveis, podem ocorrer, durante o tratamento, porém, a longo prazo, os seus efeitos são desconhecidos ${ }^{16,34,48,89}$. Vários autores demonstram suas inquietações quanto à citotoxicidade do peróxido de carbamida e a presença dos radicais livres como subproduto $15,33,73,74,75,80,93,94$.

Sabe-se que o ingrediente ativo do peróxido de carbamida é o peróxido de hidrogênio e que, durante o processo clareador, ocorre liberação de radicais livres por oxidação como o íons hidroxila e ânions superóxidos que são espécies reativas e podem promover tumores $^{14,56,75,93}$. O mecanismo de ação desses radicais ainda não é totalmente conhecido, sabe-se que uma quantidade de $\mathrm{H}_{2} \mathrm{O}_{2}$ pode penetrar nas células e danificar os componentes internos das mesmas depois de consumir os seus mecanismos de proteção ${ }^{13}$. Em condições normais, os mecanismos de proteção a esses radicais são adequados para prevenir extensos danos nas células. Entretanto, quando uma quantidade excessiva de radicais de oxigênio estão dentro da célula, ocorre uma sobrecarga nas defesas intracelulares causando a sua morte ${ }^{14}$. O organismo possui mecanismos de defesas bioquímicas intracelulares que reagem com os radicais livres para inativá-los, como por 
exemplo, o sistema enzimático. Porém, este mecanismo pode sofrer interferências no processo de reparo causando alterações e possivelmente permitindo a fixação da lesão na célula $^{29,30}$. Os radicais livres quando entram nas células rapidamente são combatidos, entretanto, dependendo da quantidade e do tipo de radicais, alguns não são eliminados e provocam reações indesejáveis, como danos ao DNA, que pode ser o início necessário para produzir um tumor ${ }^{29,30}$.

Em nosso trabalho observamos que nos grupos I (Acetona), controle do DMBA e VII (Água destilada), controle geral, não houve desenvolvimento de lesões neoplásicas e/ou displásicas mantendo a normalidade até o final do experimento. Nos grupos II e III que receberam apenas o peróxido de carbamida a 10\% com carbopol (Opalescence) e sem carbopol (White \& Brite) respectivamente não houve alterações displásicas e sim inflamação da mucosa, o que nos mostra que o peróxido de carbamida a $10 \%$ isoladamente não iniciou neoplasias. No grupo IV (DMBA), de 10 animais, 60\% desenvolveram carcinomas e, 40\% displasias, no período de 20 semanas, estando de acordo com o trabalho de $\mathrm{FASSONI}^{27}$ onde, no mesmo período experimental, houve o desenvolvimento de 50\% de carcinomas DMBA-induzidos e 20\% de lesões displásicas.

No grupo V (peróxido de carbamida a 10\% com carbopol (Opalescence) + DMBA), dos 9 animais todos desenvolveram carcinomas invasivos ou microinvasivos (100\%) e no grupo VI (peróxido de carbamida a $10 \%$ sem carbopol (White \& Brite) + DMBA), de 9 animais, 1 apresentou hiperplasia intensa e 8 carcinomas invasivos (90\%). Nos grupos $\mathrm{V}$ e VI em que os clareadores foram associados ao DMBA houve o desenvolvimento de lesões neoplásicas, mais especificamente, carcinomas epidermóides com severo grau de invasão no período de 20 semanas, em comparação com o grupo IV que recebeu apenas o DMBA (Figura 1). A organização dos tecidos, a relação intercelular 
e o modelo de invasividade são condizentes com a diferenciação celular. Estes achados corroboram com os resultados de FuJITA, et al. ${ }^{31}$, MAREFAT $^{60}$, MAREFAT;SHKLAR $^{61}$, EVESON; MACDONALD ${ }^{25}$; SALLEY $^{81}$. Histologicamente, as células que compõem um epitélio normal apresentam uma regularidade de volume, forma e núcleo. Na displasia epitelial, ocorre uma quebra dessa normalidade morfológica epitelial, alterando seu volume e forma, devido ao crescimento celular, há uma atipia celular traduzida pelo pleomorfismo e hipercromatismo nuclear acentuado e por múltiplas mitoses atípicas e células bizarras. Em conseqüência, a organização tecidual desaparece e as células se arranjam desordenadamente, perdendo as características próprias de maturação celular que promovem sua clássica estratificação de vertical para horizontal nas camadas superficiais $^{31,32,60,79,80}$. (Figuras 4, 7 e 8 )

A associação dos clareadores com o DMBA elevou os índices tumorais evidenciando uma possível ação promotora desses clareadores; a presença ou ausência do carbopol nos clareadores não interferiu nos resultados. Os testes de Kruskal Wallis mostraram diferenças estatisticamente significantes entre os grupos experimentais $(\mathrm{p}<0.01)$. De acordo com os testes estatísticos de Mann Whitney vistos anteriormente, não houve diferenças estatisticamente significantes entre os grupos $\mathrm{V}$ (peróxido de carbamida a 10\% com carbopol (Opalescence) + DMBA) e VI (peróxido de carbamida a 10\% sem carbopol (White \& Brite) + DMBA), porém, quando comparados ao grupo IV (DMBA), apresentaram diferenças estatisticamente significantes de $(p<0,05)$. Nos grupos IV, V e VI as alterações epiteliais observadas no período de 20 semanas foram predominantemente neoplásicas contrastando com a normalidade tecidual demonstrada nos grupos I, II, III e VII (Tabela 3 e Figura 1). As comparações feitas entre as drogas testadas e o DMBA, isoladamente, tiveram o objetivo de verificar se estas também 
apresentavam um comportamento de um carcinógeno completo, ou seja, com capacidade de iniciar e promover lesões ${ }^{79}$. Assim, ficou evidenciado que os clareadores não atuam na fase de iniciação, pois não foram observadas alterações macro ou microscópicas, quando foram usados isoladamente. No entanto, esses clareadores testados em associação com o DMBA exacerbaram as modificações teciduais e neoplásicas com o desenvolvimento de lesões mais severas quando comparadas ao DMBA (Grupo IV), estabelecendo assim uma ação na fase promotora do desenvolvimento tumoral (Tabela 4 e Figura 1).

Considerando-se que o peróxido de carbamida a $10 \%$ se dissocia em contato com a saliva em 3,6\% de peróxido de hidrogênio nosso trabalho corrobora de maneira mais intensa com os achados de WEITZMANN et al. ${ }^{94}$, em que os animais que receberam DMBA $+3 \%$ de peróxido de hidrogênio, produziram 55\% de carcinomas em um período de 22 semanas. Ambas as pesquisas demonstraram o potencial carcinogênico das substâncias clareadoras testadas, provavelmente atuando na fase de promoção.

Em relação aos agentes clareadores existem poucos trabalhos investigando a sua toxicidade, tanto em relação ao peróxido de hidrogênio como ao peróxido de carbamida. Tem sido demonstrado que a ingestão do peróxido de hidrogênio sozinho não determina o aparecimento de mudanças neoplásicas e sim de hiperplasias. Porém, quando o peróxido de hidrogênio a $1,5 \%$ é associado a um conhecido carcinógeno (methylazoxymethanol acetato - MAN) e administrado por várias semanas, ocorrem adenocarcinomas duodenais, evidenciando que a toxicidade da substância pode se manifestar a longo prazo $^{49}$. A ingestão do peróxido de hidrogênio em baixas concentrações, como ocorre na dissociação do peróxido de carbamida, associado a um carcinógeno provoca o aparecimento de carcinomas $^{43}$. 
Quando ingerido em dosagens superiores a 10\%, o peróxido de hidrogênio pode acarretar significantes patologias. Alguns casos fatais são reportados na literatura envolvendo crianças que ingeriram, acidentalmente, o peróxido de hidrogênio nas concentrações de $30 \%$ e $35 \%$. Dentre as alterações avaliadas pôde-se notar erosões nas paredes estomacais, eritemas nos esfíncteres esofagianos e queimaduras gástricas ${ }^{17,35}$.

A segurança dos clareadores caseiros é questionável diante de tantas evidências quanto aos riscos da substância, no organismo, pelo seu efeito sistêmico ainda pouco estabelecido $^{2,9,23,33,87,90}$. Esses clareadores, na época em que foram lançados como produtos para o uso caseiro, foram considerados como produtos cosméticos pela FDA (U.S. Food and Drug Administration). Esta classificação foi mantida até 1991, quando por preocupação quanto à segurança dos produtos, foram reclassificados como drogas e em 1992 foram colocados para serem reexaminados até que mais pesquisas sejam concluídas e os fabricantes foram orientados, na época, para retirarem seus produtos do $\operatorname{mercado}^{23,34,45,89,91}$

Nos Estados Unidos, os produtos classificados como cosméticos não passam pela avaliação da FDA, quanto ao contato com tecidos moles, como é o caso dos clareadores $^{34}$. A polêmica surgiu a partir desta classificação, pois os clareadores caseiros, quando se dissociam, liberam peróxido de hidrogênio, em concentrações superiores a 3\%, que ficam em contato com a mucosa bucal por várias horas.

O protocolo estabelecido pela Associação Dentária Americana (ADA) ${ }^{20}$ parece equivocado, pois recomenda que se façam testes em roedores nos casos em que os testes com DNA se mostrarem positivos. Porém, há evidências de que $25 \%$ a $30 \%$ das respostas negativas aos testes de genotoxicidade, de fato respondem positivamente nos testes de carcinogênese em roedores $^{12}$. Assim consideramos que os testes com roedores deveriam 
complementar os testes de genotoxidade e somente após verificar a inocuidade dessas drogas é que deveriam ser liberados os estudos clínicos em humanos. É lamentável que o Conselho da ADA já estabeleça diretrizes para estudos clínicos, sem que estudos em roedores tenham evidenciado a inocuidade ou a não participação dessas drogas na carcinogênese.

Na vida moderna, é praticamente impossível uma pessoa ficar protegida da ação de inúmeros iniciadores provenientes do nosso meio ambiente, dos hábitos sociais e alimentares. Desta maneira, a prevenção da carcinogênese deve ser feita através da menor exposição possível aos agentes químicos já conhecidos que atuam na fase de promoção das neoplasias. O uso prolongado dos agentes clareadores caseiros à base de peróxido de carbamida a $10 \%$ coloca o peróxido de hidrogênio em contato direto com a mucosa bucal por várias horas, colocando o paciente em risco com este tipo de tratamento. A avaliação longitudinal do efeito potencializador dos agentes clareadores na etiopatogenia do câncer bucal depende de vários estudos epidemiológicos complexos pelas seguintes razões: a) A etiopatogenia do câncer bucal é multifatorial. Vários agentes atuam sinergicamente e estão implicados fatores inerentes ao organismo do indivíduo, ou seja, a hereditariedade implica em considerar um fator predisponente individual; b) a necessidade de um controle populacional do ponto de vista epidemiológico com relação às suas condições de vida. Em nosso meio, frente às condições sócio-econômicas do nosso desenvolvimento, isto ainda não é possível de ser planejado. Provavelmente, nos países mais desenvolvidos, estudos desta natureza possam estar sendo desenvolvidos; c) em casos clínicos instalados de câncer bucal ainda é impossível afirmar, com um mínimo de precisão metodológica qual o principal fator etiológico naquele caso específico. O fumo, o álcool e os raios solares podem ter iniciado o câncer, ainda sem a promoção e a progressão do mesmo, 
porém, um mínimo efeito somatório requerido para esta promoção pode ter sido um dos vários agentes potencializadores presentes na boca. Determinar se este agente foi ou não o clareador dentário ainda não é possível, mas reconhecer a capacidade deste clareador para fazê-lo foi um dos objetivos deste trabalho.

Os resultados deste trabalho reforçam a sugestão de que o clareamento caseiro se constitui em um procedimento de risco para os pacientes e, portanto, não se justifica sua indicação. O procedimento adotado deve ser para proteger a mucosa do paciente, evitando o contato e até mesmo a ingestão do clareador. Isto é possível realizando o clareamento, no consultório, sob isolamento absoluto e totalmente controlado pelo profissional. Desta forma, estaremos cuidando do principal interesse para o paciente: manter sua saúde sem riscos desnecessários ou que possam ser evitados. 


\section{7 - CONCLUSÕES}




\section{7 - CONCLUSÕES}

A partir dos resultados obtidos, verificou-se que:

- Os agentes clareadores à base de peróxido de carbamida a $10 \%$ não induzem alterações epiteliais hiperplásicas nos locais das aplicações, quando atuam isoladamente. Desta forma, os agentes clareadores, isoladamente não apresentam potencial carcinogênico para iniciar neoplasias. Ressaltando-se que a ação isolada destes agentes sobre a mucosa bucal não ocorre, pois estamos em contato com várias substâncias químicas capazes de iniciar ou promover lesões tumorais..

- Quando aplicado conjuntamente com o DMBA, o agente clareador com ou sem carbopol potencializa o efeito carcinogênico. Desta forma, considerando o caráter somatório das alterações carcinogênicas nas células, este efeito potencializador também pode acontecer com os demais agentes carcinógenos que atuam sobre a mucosa bucal. Assim, provavelmente, sua ação se faz na fase de promoção da carcinogênese.

A partir dessas verificações pôde-se concluir que o uso de agentes clareadores sobre a mucosa bucal representa mais um dos fatores que podem potencializar a ação de vários carcinógenos, tais como: os provenientes do vício de fumar, a ingestão excessiva de álcool e a exposição aos raios solares, além das substâncias químicas industrialmente 
utilizadas nos alimentos sólidos e líquidos, nos remédios e os encontrados nos gases industriais.

A utilização dos clareadores dentários, na técnica caseira, colocam estes agentes clareadores, promotores da carcinogênese, em contato com a mucosa bucal do paciene por horas seguidas. Nossos resultados sugerem que esta conduta deva ser desaconselhada e este tipo de clareação dentária executada pelo profissional, com isolamento absoluto dos dentes e em seu consultório. 


\section{REFERÊNCIAS BIBLIOGRÁFICAS}




\section{REFERÊNCIAS BIBLIOGRÁFICAS*}

1 - ADEPT. Lightening Natural Teeth - ADEPT Report. v.2, n.1,p. 1-24, Winter 1991.

2 - ANDERSOn, M. H. Dental bleaching. Curr Opinion Dent., v. 1, n, 2, p.185-191, Apr. 1991.

3 - AUTIAN, J. Carcinogenic potential of metals. CDA Journal, v.12, n. 10, p. 23-33. Oct. 1984.

4 - AYRES, M.; AYRES Júnior, M. Aplicações estatísticas em Basic. São Paulo, McGraw-Hill, 1987, p. 179-204.

5 - BAILEY, S. J.; SWIFT Júnior, E. J. Effects of home bleaching products on composite resins. Quintessence Int., v. 23, n. 7, p. 489-94, 1992.

6 - BARTletT, D. W.; WALMSley, A. D. Home bleaching. Dent. Update, p. 287-90, Sept. 1992.

* Normas recomendadas para o uso no âmbito da Universidade de São Paulo, com base no documento "Referências Bibliográficas: exemplos" emanado do Conselho Supervisor do Sistema Integrado de Bibliotecas da USP, em reunião de 20 de setembro de 1990 
7 - BARRETTO NETTO, M. Patologia ambiental. In: MONTENEGRO, M. R.; FRANCO, M. Patologia: processos gerais. $3^{\text {a }}$ edição São Paulo, Ateneu, 1992, p. 217-27.

8 - BERENBLUM, M.D. The mecanism of carcinogenesis. A study of the significance of cocarcinogenic action and related phenomena. Cancer Res., v. 1, p. 807-14, Oct. 1941.

9 - BERRY, J. H. What about whiteners? J. Amer. dent. Ass., v. 121, p. 223-5, Aug. 1990.

10 - BLOT, W. J. Alcohol and cancer. Cancer Res., v. 52, p. 2119s - 2123s, Apr. 1992, Supplement.

11 - BLOT, W. J. et al. Smoking and drinking in relation to oral and pharyngeal cancer. Cancer Res., v. 48, p. 3282-7, June 1988.

12 - CAMARGO, J. L. V. et al. A detecção de substâncias cancerígenas em estudos experimentais. Rev. bras. Cancer., v. 40, n.1, p. 21-30, 1994.

13 - CANTONI, O ; MURRAY, D.; MEYN, R. E. Effect of 3-aminobenzamide on DNA strand-break rejoining and cytotoxicity in $\mathrm{CHO}$ cells treated with hydrogen peroxide. Bioch. Bioph. Acta 867, p. 135-143, 1986. 
14 - CARLSSON, J. Salivary peroxidase: an important part of our defense against oxygen toxicity. J. Oral Pathol. v. 16, p. 412-6, 1987.

15 - CHERRY, D. V. et al. Acute Toxicological effects of Ingested tooth whitners in Female rats. J. dent. Res., v. 72, n. 9, p. 1298-1303, Sept. 1993.

16 - Christensen, G. J. To Bleach or not to bleach? J. Amer. dent. Ass., v. 122, p. 64-65, Dec. 1991.

17 - CHRISTENSEN, D. W. et al. Fatal oxygen embolization after hydrogen peroxide ingestion. Critical Care Medicine, v. 20, n.4, 1992.

18 - COHEN, S. M.; ELLWEIN, L. B. Genetic errors, cell proliferation, and carcinogenesis. Cancer Res., v. 51, p. 6493 - 6505, Dec. 1991.

19 - CONNEY, A. H. et al. Panel discussion: nutrition and cancer conference. Cancer Res., v. 52, p. 2124s-2125s, Apr. 1992.

20 - COUNCIL ON DENTAL THERAPEUTICS - ADA Guidelines for the acceptance of peroxide-containing oral hygiene products. J. Amer. dent. Ass., v. 125, p. 1140-2, Aug. 1994. 
21 - DARNELL, D. H.; MOORE, W. C. Vital tooth bleaching: The white and brite technique. Comp. Continuing Educ. Dent., v. 11, n. 2, p. 86-94, 1990.

22 - DENEHY, G. E.; SWIFT Júnior, E. J. Single tooth home-bleaching. Quintessence Int., v. 23, n. 9, p. 595-98, 1992.

23 - DISHMAN, M. V.; BAUGHAN, L. W. Vital tooth bleaching- home use review and evaluation. Va. Dent. J., v. 69, n. 2, p. 12-21, Apr./Jun. 1992.

24 - ELZAY, R. P. Effect of alcohol and cigarrete smoke as promoting agents in hamster pouch carcinogenesis. J. dent. Res., v. 48, n. 6, p. 1201-5, 1969.

25 - EVESON, J.W.; MACDONALD, D.G. Hamster tongue carcinogenesis. I. Characteristics of the experimental model. J. Oral Pathol., v.10, p. 322-31, Sept./Oct. 1981 .

26 - FASANARO, T.S. Bleaching teeth: history, chemicals, and methods used for common tooth discolorations. J. Esthet. Dent., v. 4, n.3, p. 71-78, may/june 1992.

27 - FASSONI., A. A. et al. Carcinogênese bucal químicamente induzida por DMBA: estudo experimental em hamsters sírios dourados. Rev. FOB, v. 7, n. 4, p.28591, out./dez. 1993. 
28 - FREEDMAN, A.; SHKLAR, G. Alcohol and hamster buccal pouch carcinogenesis. Oral Surg., v. 46, n.6, p.794-805, Dec. 1978.

29 - FREEMAN, B. A.; CRAPO, J. D. Biology of disease - free radicals and tissue injury. Lab. Invest., v. 17, n. 5, p. 412-26, 1982.

30 - FRIDOVICH, I. The biology of oxygen radicals, Science, v. 201, n. 8, p. 875-80, Sept. 1978.

31 - FUJITA, K. et al. Experimental production of lingual carcinomas in the hamsters by local application of 9, 10- Dimethyl-1,2-Benzanthracene. J. dent. Res., v. 52, n. 2, p. 327-32, Mar./Apr. 1973.

32 - FUJITA, K. et al. Experimental production of lingual carcinoma in hamsters: tumor caracteristics and site of formation. J. dent. Res., v. 52, n. 6, p. 1176-85, Nov./Dec.1973.

33 - GAGE, T. W.; FRAZIER, L. W.; WRIGHT, J. M. Oral soft tissue response to topically applied peroxide tooth Whitener. J. dent. Res., v. 71, p. 585, 1992./Abstract n. 558/ 
34 - GOLDSTEIN, G. R.; KIREMIDJIAN-SCHUMACHER, L. Bleaching: is it safe and effective? J. prosth. Dent, v. 69, p. 325-8, Mar. 1993.

35 - GIUSTI, G. V. Fatal poisoning with hydrogen peroxide. Forensic Science, v. 2, p. 99-100, 1973.

36 - GUIMARÃES, S. A C. Neoplasias. In: Patologia básica da cavidade bucal. Rio de Janeiro, Guanabara Koogan, 1982. p. 316-412.

37 - HARRIS,R. C. G. Environment and the origin of cancer. Quintessence Int., n. 9, p. 77-82, Sept. 1973.

38 - HAYS, G. L. et al., Co-carcinogenesis and field cancerization: oral lesions offer first signs. J. Amer. dent. Ass., v. 126, p. 47-51, Jan. 1995.

39 - HAYWOOD, V. B.; HEYMANN, H. O Nigthguard vital bleaching Quintessence Int., v. 20, n. 3, p. 173-6,1989.

40 - HAYWOOD, V. B. et al., Nigthguard vital bleaching: effects of various solutions on enamel surface texture and color. Quintessence Int., v. 21 n. 10, p. 801 -4, 1990 
41 - HAYWOOD, V. B. History and effectiveness of current bleaching echinique and applications of the nightguard vital bleaching technique. Quintessence Int., v 23, n. 7, p. 471-88, 1992.

42 - HIGGINSON, J. Environmental carcinogenesis. Cancer, v. 72, n. 3, p. 971-7, Aug. 1993. Supplement.

43 - HIROTA, N.; YOKOYAMA, T. Enhancing effect of hydrogen peroxide upon duodenal na upper jejunal carcinogenesis in rats. Gann, v. 72, p. 811-12, Oct. 1981.

44 - HOMBURGUER, F. Chemical carcinogenesis in the syrian golden hamster. A review. Cancer. v. 23, p.313-38, Feb. 1969.

45 - HOWARD, W. R. Patient-applied tooth whiteners are they safe, effective with supervision? J. Amer. dent. Ass., v. 123, p. 57-60, Feb. 1992.

46 -HUMMERT, T. W. et al. Mercury in solution following exposure of various amalgams to carbamide peroxide. Amer. J. Dent., v. 6, n. 6, p. 305-9, Dec. 1993.

47 - IMLAY, J. A.; LINN, S. DNA Damage and oxygen radical toxicity. Science, v. 240, n. 3, p. 1302-9, Jun. 1988. 
48 - ISQUIERDO, J. N. Inducción, crecimiento y conducta biológica de neoplasias orales experimentales. ALAFO, v. 14, n. 2, p. 109-13, jul. 1979.

49 - ITO, A. et al. Induction of duodenal tumors in mice by oral administration of hydrogen peroxide. Gann, v.72, p. 174-5, Feb. 1981.

50 - JOVANOVIC, A. S. et al., Tobacco and alcohol related to the anatomical site of oral squamous cell carcinoma. J. Oral Pathol. Med., v. 22, p. 459-62, 1993.

51 - KATZ, H. C.; SHEAR, M.; ALTINI, M. A critical evaluation of epithelial dysplasia in oral mucosal lesions using the Smith-Pindborg method of standardization. J. Oral Pathol. v. 14, n. 6, p. 476-82, 1985.

52 - KELLER, A. Z.; TERRIS, M. The association of alcohol and tobacco with cancer of the mouth and pharynx., A. J. P. H., v.55, n. 10, p. 1578-85, Oct. 1965.

53 - KONDO, M.; TSUCHIKWA, K.; KATO, J. Experimental analisys on the chemically induced carcinoma. Two-phase carcinogenesis (The 2nd. experiment.) Shigaku, v. 74, n. 6, p. 1283-302, 1987.

54 -KWONG, K. et al. Evaluation of a 10\% carbamide peroxide gel vital bleaching agent. N. Z. dent J. v. 89, p. 18-22, Jan. 1993. 
55 - LARSON, T. D. The Effect of Peroxides on Teeth and Tissue Review of the Literature. Northwest Dentistry, p. 29-32, Nov./Dec. 1990.

56 - LARSSON, K. S., Potential teratogenic and carcinogeneic effects of dental materials, Int. dent. J, v.41, n. 4, p.206-11, 1991.

57 - LEONARD Jr, R. H. et al. Change in $\mathrm{pH}$ of plaque and $10 \%$ carbamide peroxide solution during nightguard vital bleaching treatment. Quintessence Int., v. 25, n. 12, p. 819-23, 1994.

58 - LEONARD Jr, R. H.; BENTLEY, C.; HAYWOOD, V.B. Salivary pH changes during $10 \%$ carbamide peroxide bleaching. Quintessence Int., v. 25, n. 8, p. 547-49, 1994.

59 - LOPES, E. R. et al. Câncer e meio ambiente - tabaco - agrotóxicos - radiações dieta. Um documento para a Conferência Mundial de Ecologia. Rev. bras. Cancer. v. 38, n.1, p. 35-64, 1992.

60 - MAREFAT, M. P. The effect of the short dose schedule of DMBA application in inducing lingual neoplasia in inbred Syrian hamster. J. Oral Pathol., v. 14, n. 5, p. 383-9, 1985. 
61 - MAREFAT, P.; SHKLAR, G. Experimental production of lingual leukoplakia and carcinoma. Oral Surg., v. 44, n. 4, p. 578-86, Oct. 1977.

62 - McGUCKIN, R.; BABIN, J. F.; MEYER, B. J. Alterations in human enamel surface morphology following vital bleaching. J. prosth. Dent., v. 68, n. 5, p. 754-60, Nov. 1992.

63 - MENDONÇA, G. A. e S. Câncer no Brasil: um risco crescente. Rev. bras. Cancer., v. 38, n.4, p. 167-76, 1992.

64 - MILLER, E. C. Some current perspectives on chemical carcinogenesis in human and experimental animals: presidential address. Cancer Res, v. 38, p. 1479-96, Jun. 1978.

65 - MILLER, E. C.; MILLER, J. A. Mechanisms of chemical carcinogenesis Cancer. v. 47 , p. 1055-64, 1981.

66 - MILNER, J. A. Dietary antioxidants and cancer. J Dent. Child., p. 140-143, Mar./Apr.1986.

67 - MORRIS, A L. Factors influencing experimental carcinogenesis in the hamster cheek pouch. J. dent. Res., v. 40, n. 1, p. 3-15, Jan./Feb. 1961. 
68 - NELSON, N. Cancer prevention: environmental, industrial and occupational factors Cancer, v. 47, n. 5, p. 1065 - 70, 1981.

69 - ODUKOYA, O; SHKLAR, G. Initiation and promotion and experimental oral carcinogenesis. Oral Surg., v. 58, n. 3, p. 315-20, Sept. 1984.

70 - ODUKOYA, O; SHKLAR, G. Two-phase carcinogenesis in hamster buccal pouch. Oral Surg., v. 54, n. 5, p. 547-52, Nov. 1982.

71 - PIEROLI, D. A.; NAVARRO, M. F. de L. Clareação de dentes vitalizados: considerações gerais. Rev. bras. Odont. Nac., v. 4, n. 4, p.244-48, ago./set. 1996.

72 - PLOEGER, B. J. et al. Quantitative in vivo comparison of five carbamide peroxide bleach gels. J. dent. Res., p. 376./Abstract n. 889/

73 - POWELL, L. V., BALES, D. J. Tooth bleaching: its effect on oral tissues. J. Amer. dent. Ass., v. 122, p. 50-54, Nov. 1991.

74 - POWERS, J. M.; FARAH, J. LW. Produtos Clareadores Fluoretos. The Dental Advisor, v. 4, n. 1, p.2-8, 1996. 
75 - REES, T. D., ORTH, C. Oral ulcerations with use of hydrogen peroxide. J. Periodont., p. 689-92, Nov. 1986.

76 - RODRIGUES, M. A. M.; CAMARGO, J.L.V. Carcinogênese. In:. MONTENEGRO, M. R.; FRANCO, M. Patologia: processos gerais. p. 193-203, 3ª edição, São Paulo, Editora Ateneu, 1992.

77 - ROBBINS, S. L.;COTRAN, R. S.; KUMAR, V. Neoplasia In Pathologic basis of disease. 4⿳⺈ edição Philadélfia, Saunders, 1989, p. 239-305.

78 - RUBIN, E.; FARBER, J. L. Patologia. Rio de Janeiro, Interlivros, 1990.

79 - SALLES, C. L. F. et al. Avaliação do potencial carcinogênico do formocresol diluído a $1 / 5$ e dogGlutaraldeído a $2 \%$ no modelo experimental DMBAinduzido. Rev. FOB, v. 2, n. 3, p. 5-11, jul./set. 1994.

80 - SALLEY, J. J. Experimental carcinogenesis in the cheek pouch of the syrian hamster. J. dent. Res., v. 33, n. 2, p. 253-62, Apr. 1954.

81 - SALLEY, J. J. Histologic changes in the hamster cheeck pouch during early hydrocarbon carcinogenesis. J. dent. Res., v. 36, n. 1, p. 48-55, Feb. 1957. 
82 - SALTZ, E., Projeto de expansão da prevenção e controle do câncer de boca Quinquênio 1988-93. Rev. bras. Cancer., v. 34, n. 4, p. 221-39, 1988.

83 - SHKLAR, G. The effect of manipulation and incision on experimental carcinoma of hamster buccal pouch. Cancer Res., v. 28, p. 2180-2, Nov. 1968.

84 - SHAW, M. W. Human chromossome damage by chemical agents. Ann. Rev. Med., v. 21, p. 409-32, 1970.

85 - SHEARER, A. C. External bleaching of teeth. Dent. Update, p. 289-91, Sept. 1991.

86 - SHIPMAN, B.; COHEN,E.; KASLICK, R. S. The Effect of a urea peroxide gel on plaque deposits and gigival status. J. Periodont., v. 42, n. 5, p. 283-85, May 1971.

87 - SIEGEL, S. Estatística não paramétrica para as ciências do comportamento. São Paulo, McGraw-Hill, 1977, p. 131-44, 302-8, 209-18, 313-4.

88 - SIMONSEN, R. J. Home bleaching - is there scientific support? Quintessence Int., v. 21, n. 12, p. 931, 1990.

89 - SPORN, M. B. Carcinogenesis and cancer: different perspectives on the same disease. Cancer Res., v. 51, p. 6215-18, Dec. 1991. 
90 - STRASSLER, H. E.; SCHERER, W.; CALAMIA, J. R. Carbamide peroxide athome bleaching agents N.Y. St. dent. J., v. 58, n. 4, p. 30-5, Apr. 1992.

91- TAM, L. Vital tooth bleaching: review and current status. J. Canad. dent. Ass., v. 58 , n. 8, p. 654-663, Aug. 1992.

92 - WANDERA, A. et al., Home-use tooth bleaching agents: na in vitro study on quantitative effects on enamel, dentin and cementum. Quintessence Int., v. 25, n. 8 , p. $541-46,1994$.

93 - WEITZMAN, S. A. et al. Chronic treatment with hydrogen peroxide: Is it Safe? J. Periodont., v. 55, n.9, p. 510-11, 1984.

94 - WEITZMAN, S.A et al. Effects of hydrogen peroxide on oral carcinogenesis in hamsters. J. Periodont., v. 57, p. 685-8, Nov. 1986.

95 - W. H. O - Definition of leukoplakia and related. An aid studies on oral precancer. Oral Surg., v. 46, n. 4,p. 518-39, Oct. 1978. 
ABSTRACT 


\begin{abstract}
In carcinogenesis there is an addition of effects in cells. Besides smoke, alcohol and solar radiation, a lot of potencially carcinogenic noxious products in foods, medications and from the environment get in contact with the oral mucosa. Bleaching agents of vital teeth can be applied by the patients at home in trays, the "nightguard vital bleaching". The effects of two bleaching agents, based on a $10 \%$ carbamide peroxide solution with and without carbopol, were evaluated by the DMBA-induction experimental model of carcinogenesis. For twenty weeks, seven experimental groups were evaluated. Each group contained 10 hamsters and the following products were applied on the medial lateral border of the tongue: acetone, non-carbopol-containing $10 \%$ carbamide peroxide and carbopol containing $10 \%$ carbamide peroxide, DMBA $+10 \%$ carbamide peroxide with carbopol, DMBA $+10 \%$ carbamide peroxide without carbopol and destilled water. Ten animals died during the experiment. The groups receiving acetone, $10 \%$ carbamide peroxide with and without carbopol and destilled water showed no displasic alterations. In the group receiving DMBA alone, four animals developed displasias and six developed squamous cell carcinomas, three being micro-invasive and three invasive carcinomas. For group receiving DMBA and $10 \%$ carbamide peroxide with carbopol, all nine animals developed squamous cell carcinomas, two being micro-invasive and seven invasive carcinomas. When DMBA and $10 \%$ carbamide peroxide without carbopol was applied, one out of nine animals presented intense hiperplasia and eight invasive squamous cell carcinomas. It was concluded that bleaching agents enhance the effect of other carcinogenic agents, acting probably in the phase of promotion, without interfering in the tumoral initiation phase.
\end{abstract}

